\title{
The Role of Tumor Microenvironment in the Pathogenesis of Sézary Syndrome
}

\author{
Denis Miyashiro ${ }^{1,2, * \mathbb{D}}$, Bruno de Castro e Souza ${ }^{1}$, Marina Passos Torrealba ${ }^{3}$, Kelly Cristina Gomes Manfrere ${ }^{3}$, \\ Maria Notomi Sato ${ }^{3}$ id and José Antonio Sanches ${ }^{1,2}$ (D)
}

1 Division of Clinical Dermatology, University of São Paulo Medical School, Sao Paulo 05403-900, Brazil; brunocastro1990@hotmail.com (B.d.C.e.S.); jasanches@usp.br (J.A.S.)

2 Instituto do Câncer do Estado de São Paulo, University of São Paulo Medical School, Sao Paulo 01246-000, Brazil

3 Laboratory of Medical Investigation, LIM-56, Department of Dermatology, Tropical Medicine Institute of São Paulo, University of São Paulo Medical School, Sao Paulo 05403-000, Brazil; marinatorrealba@usp.br (M.P.T.); kellycgmanfrere@usp.br (K.C.G.M.); marisato@usp.br (M.N.S.)

* Correspondence: denisrmiyashiro@gmail.com; Tel.: +55-11-9729-61705

check for updates

Citation: Miyashiro, D.; Souza, B.d.C.e.; Torrealba, M.P.; Manfrere, K.C.G.; Sato, M.N.; Sanches, J.A. The Role of Tumor Microenvironment in the Pathogenesis of Sézary Syndrome. Int. J. Mol. Sci. 2022, 23, 936. https:// doi.org/10.3390/ijms23020936

Academic Editor: Makoto Sugaya

Received: 31 October 2021

Accepted: 19 December 2021

Published: 15 January 2022

Publisher's Note: MDPI stays neutral with regard to jurisdictional claims in published maps and institutional affiliations.

Copyright: (C) 2022 by the authors. Licensee MDPI, Basel, Switzerland. This article is an open access article distributed under the terms and conditions of the Creative Commons Attribution (CC BY) license (https:// creativecommons.org/licenses/by/ $4.0 /)$.

\begin{abstract}
Sézary syndrome is an aggressive leukemic variant of cutaneous T-cell lymphomas, characterized by erythroderma, lymphadenopathy, and peripheral blood involvement by CD4+ malignant T-cells. The pathogenesis of Sézary syndrome is not fully understood. However, the course of the disease is strongly influenced by the tumor microenvironment, which is altered by a combination of cytokines, chemokines, and growth factors. The crosstalk between malignant and reactive cells affects the immunologic response against tumor cells causing immune dysregulation. This review focuses on the interaction of malignant Sézary cells and the tumor microenvironment.
\end{abstract}

Keywords: Sézary syndrome; cutaneous T-cell lymphoma; tumor microenvironment; cytokines; chemokines

\section{Introduction}

Sézary syndrome (SS) was first described by Albert Sézary and Yves Bouvrain in 1938 [1]. It is a rare and aggressive leukemic variant of cutaneous T-cell lymphoma (CTCL). Males are more affected than females (2:1), and it occurs almost exclusively in adults. The classic triad of SS includes erythroderma, lymphadenopathy, and circulating malignant cells [2]. Besides erythroderma, a diffuse non-scarring alopecia, palmoplantar hyperkeratosis, nail dystrophies, and leonine facies may be observed [3]. Intense pruritus is the most frequent symptom, and it significantly decreases the quality of life $[2,4]$. Systemic symptoms (fever, night sweats, and weight loss) are present in $1.6 \%$ of the patients [5]. Circulating Sézary cells are detected by peripheral blood smear (large lymphocytes with cerebriform nuclei) and immunophenotyping of lymphocytes by flow cytometry (CD4:CD8 $\geq 10$, CD4+CD7- $\geq 40 \%, C D 4+C D 26-\geq 30 \%$ ). A search for the T-cell receptor (TCR) gene rearrangement shows a monoclonal population of T-cells on the blood, and the exact clone is detected on skin infiltrate (Figure 1) [2,6,7].

The pathophysiology of SS is not entirely understood. The most plausible hypothesis is the activation of T-cells by antigen-presenting cells, leading to the gradual accumulation of mutations that culminates with neoplastic cell development. However, the triggering antigen is unknown, and it could vary between patients [8,9].

Mycosis fungoides (MF) and SS were considered the same disease for many years. However, neoplastic cells in these two entities have distinct origins. MF cells strongly express C-C chemokine receptor (CCR)-4 and cutaneous lymphocyte-associated antigen (CLA), which confer tropism to the skin, and are negative for CCR7 and L-selectin, receptors that confer tropism to the lymph nodes. This immunophenotype is characteristic of skinresident memory T-cells. On the other hand, Sézary cells express CCR7 and L-selectin, 
CD27 (a characteristic marker of central memory T-cells), CCR4, and other skin-tropic receptors (CCR6, CCR10, CLA). These findings suggest that MF and SS originate from different subtypes of T lymphocytes [10].
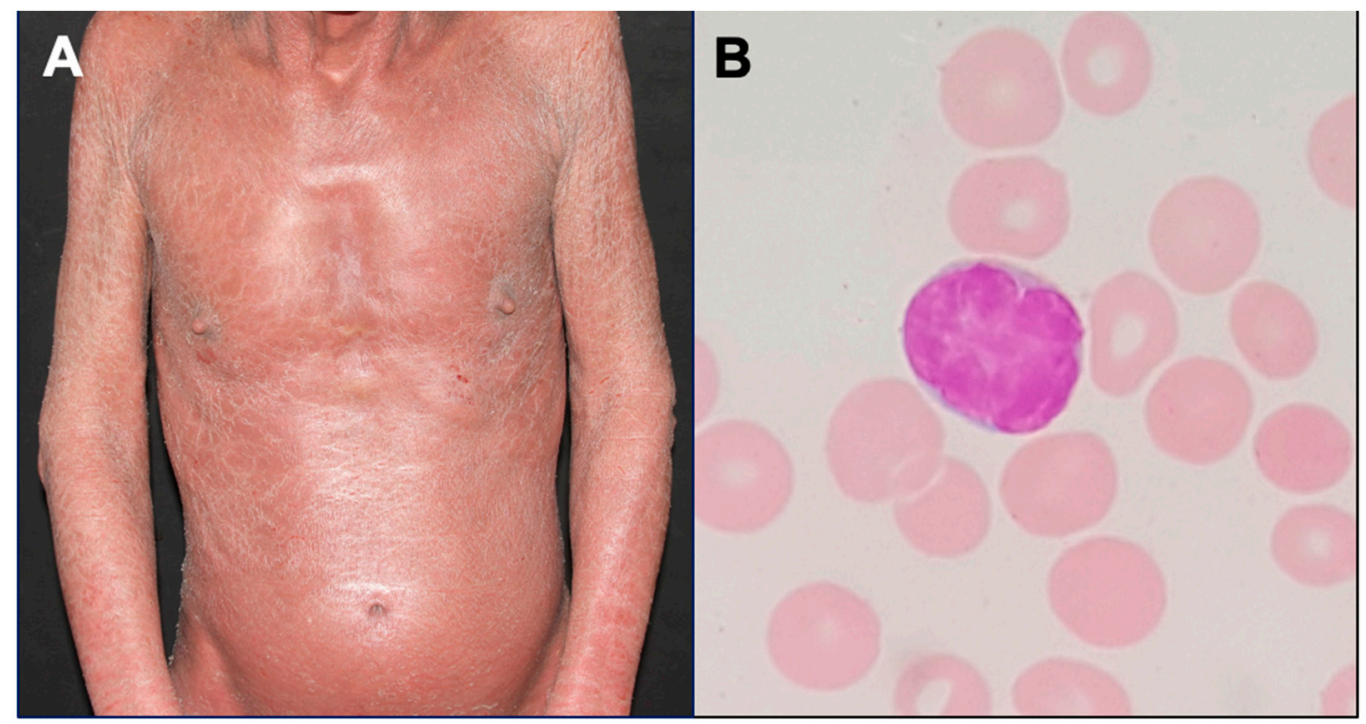

C

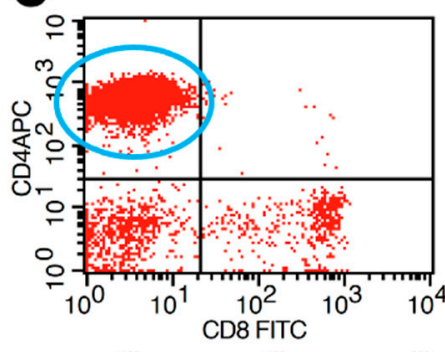

D

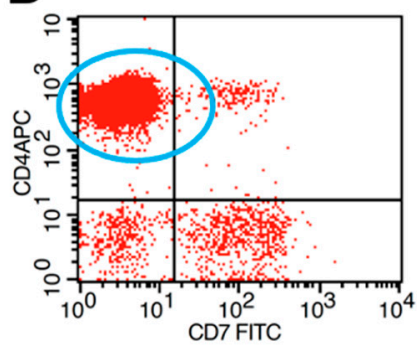

E

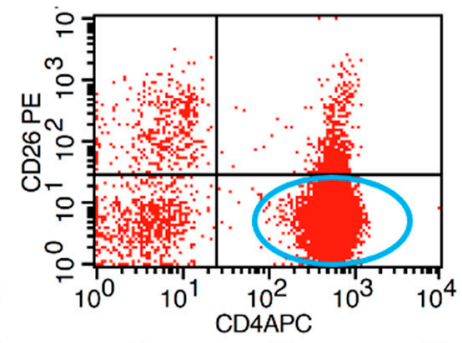

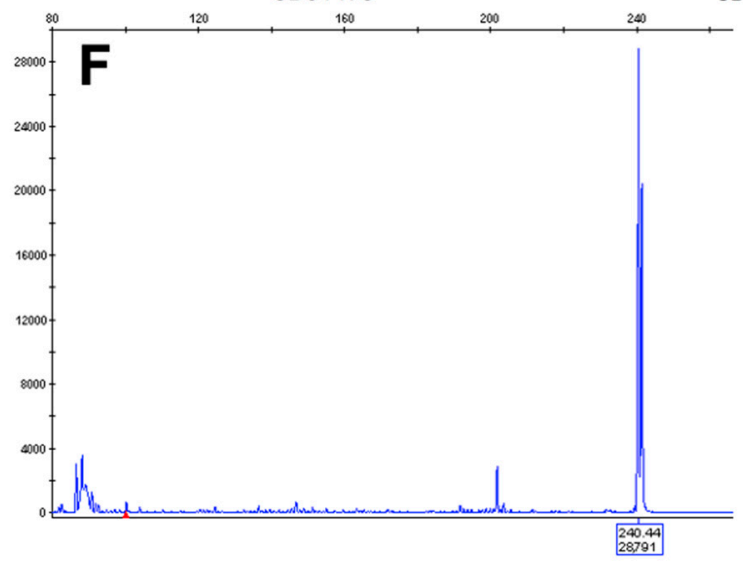

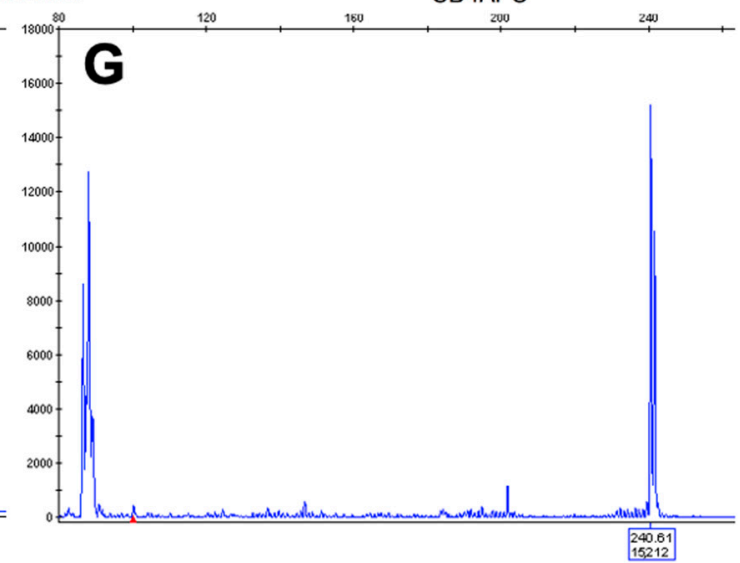

Figure 1. Sézary syndrome. Erythroderma (A). Sézary cell on a peripheral blood smear (B). Flow cytometry of peripheral blood showing the CD4+CD8- (C), CD4+CD7- (D), and CD4+CD26- (E) Sézary cells. Monoclonal T-cell population on the skin $(\mathrm{F})$ and the same clone detected on peripheral $\operatorname{blood}(\mathbf{G})$.

The prognosis of SS is poor. The five-year overall survival rates range between 40 and $50 \%[2,11]$. First-line treatment includes extracorporeal photopheresis (ECP), interferon- $\alpha$ combined with ECP or phototherapy, retinoids, chlorambucil associated with prednisone, and low dose methotrexate. Second-line treatment includes chemotherapy with gemcitabine, pegylated liposomal doxorubicin, CHOP (cyclophosphamide, doxorubicin, vin- 
cristine, and prednisone), and CHOP-like regimens, alemtuzumab (anti-CD52 monoclonal antibody), and allogeneic stem cell transplantation [12].

Response to chemotherapy is excellent; however, the disease rapidly recurs. Biologic response modifiers (ECP, interferon- $\alpha$, and retinoids) show prolonged responses, suggesting an essential role of immunomodulation in controlling neoplastic proliferation. Increasing evidence shows the influence of the tumor microenvironment characterized by reactive cells, chemokines, and cytokines in the clinical behavior of SS, and these interactions gradually drive an antitumor response towards a tolerogenic milieu $[13,14]$. Understanding the tumor microenvironment is essential to the development of new therapies to improve survival and, maybe, reach a curative treatment for this aggressive and morbid disease. This review focuses on the discussion of the current scenario of the immunologic milieu of SS.

\section{Tumor Microenvironment}

The interaction between tumor cells and the microenvironment influences the progression of CTCL. In early-stage MF, neoplastic cells are scarce and reactive T-helper (Th) 1 and CD8+ T-lymphocytes contribute to the antitumor defense [15-17]. With the disease's progression, the tumor microenvironment shifts from a Th1 to a Th2 response, and contributes to tumor cells growth and immune escape $[15,18]$.

As an aggressive CTCL, SS is a Th2-type disease, and it exhibits an exhaustion status of antitumor defense $[15,19,20]$, with increased levels of interleukin (IL)-4, IL-5, and IL-13, and reduced levels of Th1 cytokines such as IL-2 and interferon (IFN)- $\gamma$, that reduce cellmediated immunity $[18,21]$. This microenvironment favors angiogenesis, tissue remodeling, as well as survival and proliferation of malignant cells. The Th2 cytokines produced by Sézary cells suppress the Th1 response and impair cellular immunity. Reactive T-cells are present but are dysfunctional due to the Th1/Th2 imbalance [22,23].

It is not known precisely how malignant cells start this change in the tumor microenvironment. It is hypothesized that somatic mutations, somatic copy number variations, and epigenetic deregulation in Sézary cells could drive the activation of pro-oncogenic and the inhibition of tumor suppressor pathways [24,25]. However, exogenous factors, mainly Staphylococcus aureus colonization, play an important role in the emergence of the Th2 response [26]. The endogenous and exogenous factors will ultimately affect the JAK/STAT pathway, with a decrease in STAT4 (Th1) and an increase in STAT3, STAT5, and STAT6 (Th2) activation in neoplastic cells [27]. Under normal conditions, STAT proteins are transiently activated. However, in neoplastic cells, constitutive activation of STAT3, STAT5, and STAT6 occur. Aberrant activation of these transcription factors stimulates the secretion of Th2 cytokines. The Th1 transcription factor STAT4 is inhibited in SS, probably due to the action of micro-RNA (miR)-155 induced by STAT5; $[15,28]$. and GATA-3, a Th2 transcription factor, is activated through STAT6 signaling [29]. The released Th2 cytokines contribute to a positive feedback loop between malignant and reactive cells, influencing the growth and survival of the former [30].

\subsection{CD8+ T-Cells}

The CD8+ T-cells are cytotoxic lymphocytes that play an important role in antitumor response by exocytosis of intracytoplasmic granules with perforin, granzymes, and Tcell-restricted intracellular antigen-1 (TIA-1), and by a Fas-mediated pathway in which membrane-bound Fas ligand (FasL) expressed on CD8+ T-cells interacts with Fas on neoplastic cells [31]. The intensity of CD8+ T-cell infiltrate within the skin of CTCL patients is associated with a better prognosis [31].

In SS, circulating CD8+ T-cells express CD38, PD-1, Tim-3, and CD39. The CD38 is an activation marker frequently observed in chronic viral infections, and PD-1, Tim-3, and CD39 are exhaustion markers (Figure 2). T-cell exhaustion is a state of dysfunction observed in chronic infections and cancer due to the persistence of antigens and inflammation. After persistent antigen stimulation, CD8+ T-cells undergo functional loss [13]. Their cytotoxicity 
is modified, and their cytokine production ability, proliferative capacity, and effective memory cell generation are also affected. Impaired production of IFN- $\gamma$, tumor necrosis factor (TNF), IL-2, and a high expression of coinhibitory receptors are observed, which compromises their ability to fight against infections and tumor cells [19,32,33].

\section{Activation marker}

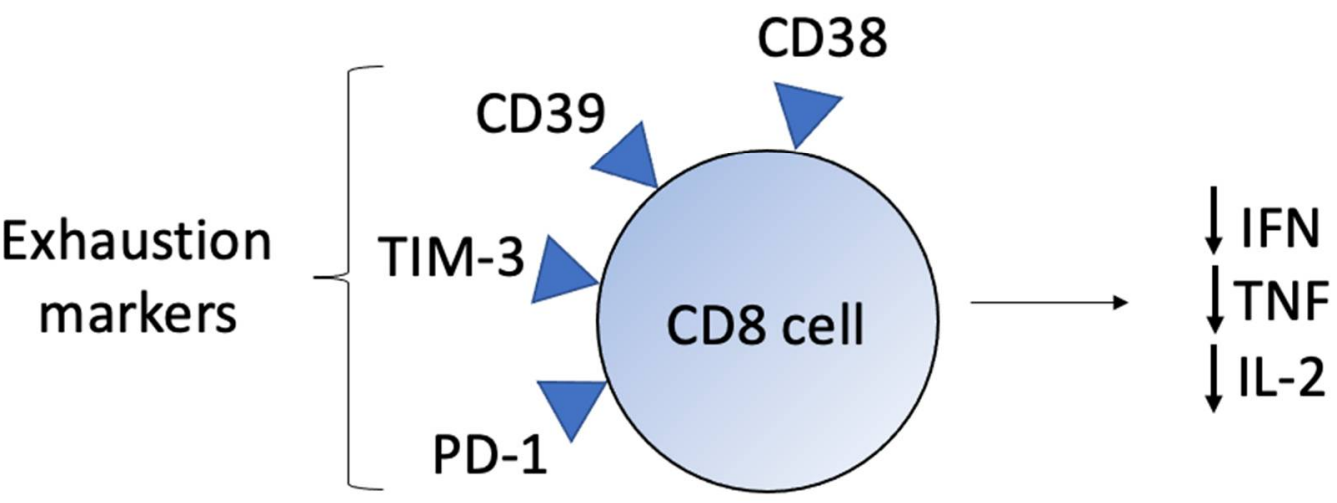

Figure 2. CD8+ T-cell characteristics in SS. Activation of CD8+ T-cells is detected by the expression of CD38, and the chronic activation leads to an exhaustion phenotype with the expression of CD39, TIM-3, and PD-1. Furthermore, in exhausted CD8+ T-cells, a functional loss is observed, with reduced production of IFN, TNF, and IL-2, decreasing the cytotoxic activity against neoplastic cells.

The IL-7 and IL-15 are growth factors essential to lymphocytic functions. The IL-7 induces IFN- $\gamma$ production and proliferation; the IL-15 contributes to the proliferation and survival of natural killer (NK) and CD8+ T-cells. Upon binding to their receptors on the cell surface, they signal via JAK1 and JAK3, which activate STAT5 [19,34,35]. In CD8+ T-cells, STAT5 induces the antiapoptotic molecule Bcl-2 expression, which is important to maintain CD8+ effector function [36-38]. In SS, CD8+ T-cells exhibit impaired STAT5 and Bcl-2 expression compared to healthy donors, even after IL-7 stimulus. These cells also exhibit increased CD95/Fas expression, which may trigger apoptosis, contributing to the decreased cytotoxic activity against neoplastic cells [19].

\subsection{Regulatory T-Cells}

The Tregs comprise five to ten percent of peripheral T-cells [39]. These cells inhibit other T-cell functions by secretion of inhibitory cytokines such as IL-10 and transforming growth factor (TGF)- $\beta$; by induction of apoptosis mediated through secretion of granzymes A/B and perforin; by expression of tumor-necrosis-factor-related-apoptosis-inducing ligand-death receptor 5 (TRAIL-DR5); by induction of Fas/FasL pathway, galectin-9 pathway, and galectin-1 secretion; by metabolic disruption, due to the metabolism of ATP to AMP and the production of adenosine (an immunoregulatory purine) and transfer of cyclic AMP to effector cells by gap junctions that lead to apoptosis by IL-2 deprivation; and by modulation of dendritic cell (DC) maturation or function through the interaction of CTLA-4 on Tregs with its ligand CD80/86 on antigen-presenting cells [40,41].

Sézary cells commonly express FoxP3 and CD25, markers observed in Tregs, and the global methylation pattern of Sézary cells are similar to the one observed in Tregs. Thus, it has been postulated that SS may represent a malignancy of Tregs in some patients [42-45]. Importantly, FoxP3 and CD25 in malignant cells do not seem to exclusively confer a suppressive phenotype. Some patients may present high levels of FoxP3 and CD25 in Sézary cells but not in other patients, in which, malignant T-cells failed to suppress T-cell proliferation [46]. There is evidence of low molecular splice forms of FoxP3 that 
are functionally different from wild type FoxP3 and not involved in the execution of the suppressive function [47]. Some factors, such as cytokines or bacterial toxins in the tumor microenvironment have been proposed to drive the heterogeneous FoxP3 expression in malignant cells [48]. The Treg properties expressed by Sézary cells are stimulated by staphylococcal enterotoxins (SEs), which trigger the expression of FoxP3 in a STAT5-dependent manner, and by direct contact with immature DCs via MHC class 2 presentation of antigens of apoptotic cells. These Sézary cells with Treg properties secrete IL-10 and TGF- $\beta$, which suppress the secretion of IL-2 and IFN- $\gamma$ and maintain DC immaturity, contributing to further neoplastic cell proliferation and up-regulation of the Treg phenotype $[23,39,49]$.

Programmed death-1 (PD-1) is an immune checkpoint inhibitor. It is increased in benign and malignant CD4+ T-cells in SS. When activated, the PD-1 axis inhibits reactive T-cells, promotes the induction of Th2 and Treg cells, and prevents apoptosis of Tregs. Thus, nonmalignant Tregs are increased in SS, contributing to the immune escape of tumor cells $[21,50,51]$

\subsection{Regulatory B-Cells}

A subset of B-cells can suppress immune responses, similar to Tregs, called regulatory B-cells (Bregs). These cells contribute to immune tolerance by secretion of IL-10 but also other inhibitory molecules, including PD-L1, granzyme B, TGF- $\beta$, and IL-35, leading to the induction of tumor immunosuppressive cells [52]. Few studies addressing the presence of Bregs in CTCL are available. Interestingly, decreased Bregs are observed in CTCL progression, and it is hypothesized that Bregs suppress the activity of tumor cells in the blood [14,53]. Other B-cells are also decreased in CTCL, such as CD19+ CD24hiCD27+ Bcells, CD19+ CD38hi B-cells, together with IL-10-producing B-cells in CTCL progression [53]. Despite the discussion that Breg may play a role in the CTCL progression, IL-10 produced by Bregs enriched in CD19+ CD24hiCD27+ B-cells could impair the function of immune cells, including Th1/CD8+/NK cells, or TGF- $\beta$ secreted by Bregs could convert CD4+ Tcells into Tregs that would promote tumor progression [54]. More studies are needed to understand whether Bregs can affect other immune cells or help to convert malignant cells to Tregs in Sézary syndrome.

\subsection{NK Cells}

The NK cells are cytotoxic lymphoid cells that constitute the innate immune system [55]. The NK cells can be divided into two main populations: CD56 ${ }^{\text {dim }}$ CD16 ${ }^{\text {bright }}$, which is predominant in the peripheral blood and has a cytolytic activity; and CD56 $6^{\text {bright }} C D 16^{\text {dim }}$, which is predominant on lymph nodes and secondary lymphoid tissue and has an immunoregulatory role [56].

The NKG2D is the main activating receptor of the NK cells, and it binds to major histocompatibility complex (MHC) class I homologs (MICA and MICB) and UL-16 binding proteins (ULPB)-1 to 5, that function as signals of cellular stress [57,58]. Upon binding to NKG2D ligand (NKG2DL) expressed in malignant cells, the NK cells attack by degranulation of perforin and granzyme and production of IFN- $\gamma$ and TNF- $\alpha$ [14]. In a process called trogocytosis, the cell-to-cell contact allows the migration of the NKG2DL of the tumor cell to the NK cell. Thus, these altered NK cells may be recognized by tumor-naïve NK cells and are killed (Figure 3) [59]. Other mechanisms that favor immune escape by malignant cells, besides the trogocytosis, are the down-regulation of NKG2D observed in NK cells from SS patients [58], and the reduced number of total NK cells and the cytolytic CD56 ${ }^{\text {dim }}$ CD16 ${ }^{\text {bright }}$ NK cells, while the immunoregulatory CD56 ${ }^{\text {bright }}$ CD16 ${ }^{\mathrm{dim}} \mathrm{NK}$ cells are preserved [60]. The downregulation of NKG2D may be due to TGF- $\beta$ and metalloproteinases [61]. The subset of CD57+NKG2C+ NK cells has been described as exhibiting memory-like features, with potent effector functions, and could be elicited by human cytomegalovirus (HCMV) infection [62]. Interestingly, besides the altered cytolytic CD56 ${ }^{\mathrm{dim}} \mathrm{NK}$ cells in SS patients, an increased percentage of CD56+CD57+NKG2C+ NK cells was found, together with high seropositivity to CMV [58]. The expansion of this mature CD57+NKG2C+ NK subset 
detected in SS patients could be due to its memory for CMV infection. The fact that trained immunity may display potent functions could be beneficial for cancer patients [63].

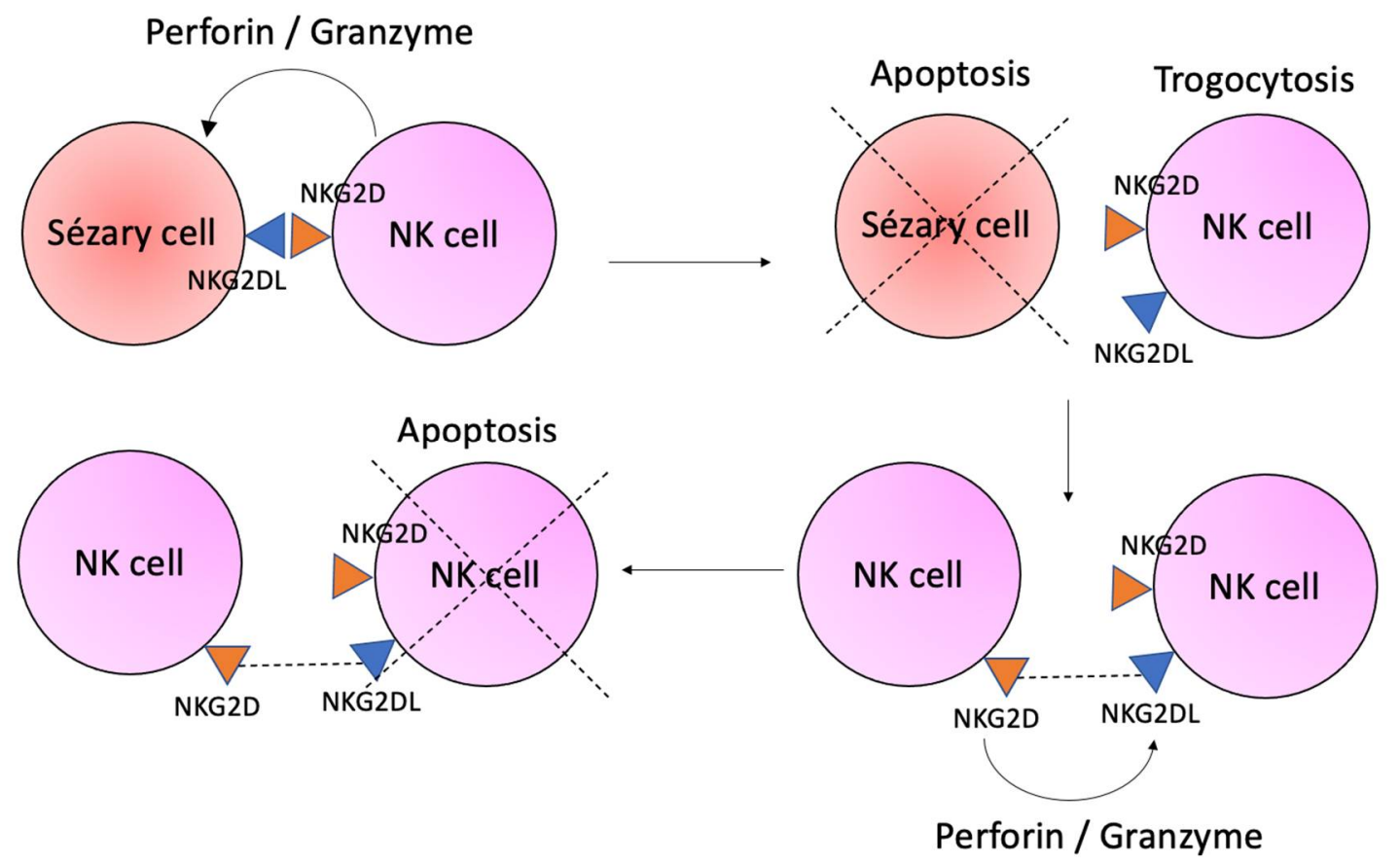

Figure 3. Trogocytosis process. The interaction of Sézary cells and NK cells by NKG2D/NKG2DL activates the degranulation of perforin and granzyme that kills malignant cells. The cell-to-cell contact allows the migration of NKG2DL from the Sézary cell to the NK cell in the trogocytosis process. The NK cell with NKG2DL is recognized by tumor-naïve NK cells that liberate perforin and granzyme, killing the NK cell.

\subsection{Dendritic Cells}

Dendritic cells (DCs) are professional antigen-presenting cells. They prompt immune responses by activating naïve T-cells at a mature state and promote tolerance by deleting self-reactive thymocytes, mediating the anergy of mature T-cells, and generating Tregs at an immature state [14]. The Th2 cytokines secreted in the SS tumor microenvironment suppress the maturation of DCs. The influence of dysregulated or immature antigen-presenting cells can explain aspects of tumor progression [18].

The IL-10 downregulates DC functions, contributing to the formation of immature DCs, that promote tolerance rather than immune defense because these cells present apoptotic cell antigens without the appropriate co-stimulation. Furthermore, direct contact with immature DCs stimulates the Treg phenotype in Sézary cells (Figure 4) [23,64-66]. An increased number of immature DCs in SS lesions is important for immunological tolerance against malignant T-cells [67]. Conversely, IFN- $\gamma$ stimulates the maturation of DCs, which inhibit Sézary cells proliferation [65,68]. Mature DCs may attempt to mount an immune response against the cancer cells via the production of the Th1 cytokines IL-12, IL-2, and IFN- $\alpha$, as mature DCs are elevated in the skin draining lymph nodes of some patients [69-71]. Another dendritic cell subset, termed plasmacytoid dendritic cells (pDCs) are highly effective in sensing intracellular viral or self DNA and RNA mainly via Tolllike receptors (TLRs) and rapidly producing large amounts of type I and III interferons (IFNs) [72]. SS patients demonstrate the gradual loss of plasmacytoid dendritic cells in the peripheral blood [71]. However, using synthetic oligodeoxynucleotides with CpG motifs (CpG ODN), an agonist of TLR9, is able to induce IFN- $\alpha$ production, by the CD123 pDC of patients with Sézary syndrome [70]. 


\section{Staphyloccocal enterotoxins}

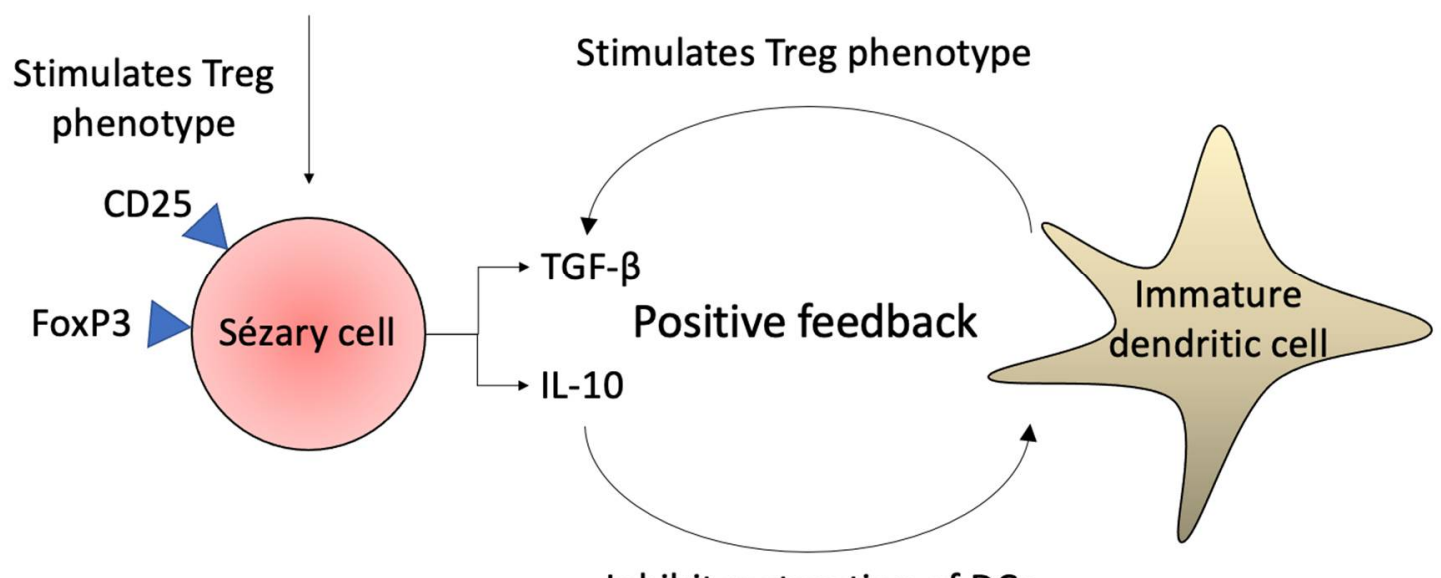

Inhibit maturation of DCs

Figure 4. Sézary cell and dendritic cell interaction. The Sézary cells express a Treg phenotype upon Staphylococcal enterotoxins stimulation. The cytokines produced by malignant cells, especially IL-10, prevent DCs from maturating; and the immature DCs promote immune tolerance and persistence of Treg phenotype in Sézary cells in positive feedback.

The observation that apoptotic neoplastic cells can induce antigen-presenting cell maturation explains why total skin electron beam and extracorporeal photopheresis, which induce massive apoptosis of malignant cells, are effective treatment regimens [23].

\subsection{Myeloid-Derived Suppressor Cells}

Myeloid-derived suppressor cells (MDSCs) are immature myeloid cells that mediate immunosuppression by JAK3/STAT3-dependent secretion of reactive oxygen species (ROS) and arginase-1 (ARG-1) into the tumor microenvironment [51,73]. These cells are generated under pathological conditions, through myelopoiesis in the bone marrow or spleen before migration to the periphery. Granulocyte-macrophage colony-stimulating factor (GM-CSF), granulocyte colony-stimulating factor (G-CSF), macrophage colony-stimulating factor (M-CSF), stem cell factor (SCF), vascular endothelial growth factor (VEGF), IL-6, S100A9, S100A8, and prostaglandin E2 (PGE2) mediate MDSCs formation. These molecules induce signaling pathways such as STAT3, STAT5, interferon regulatory factor (IRF)-8, and CCAAT/enhancer-binding protein (C/EBP)- $\beta$. The C-C ligand (CCL)-2 and CCL-5 chemokines mediate recruitment of MDSCs to tumor microenvironment by binding to a receptor present on MDSCs. Other chemokines that induce mobilization of MDSCs in the tumor microenvironment include CCL7, CCL15, CCL26, C-X-C ligand (CXCL)-8, and CXCL12 [74].

The ROS upregulation in MDSCs is mediated by nicotinamide adenine dinucleotide phosphate (NADPH) oxidase activity. ROS production has been associated with T-cell unresponsiveness and tolerance [75].

The L-arginine is a substrate for the inducible nitric oxide synthase (iNOS) and ARG-1, both expressed in MDSCs and involved in lymphocyte suppression. Deprivation of Larginine leads to T-cell dysfunction [76]. The iNOS generates nitric oxide, which is implicated in the attenuation of MHC class II expression in macrophages and in inducing T-cell apoptosis [77]. Thus, MDSCs are correlated with disease progression and resistance to therapy in hematologic malignancies. Indoleamine 2,3-dioxygenase (IDO)-dependent tryptophan catabolism is a mechanism of immunosuppression mediated by MDSCs [74,78]. MDSCs downregulate the expression of L-selectin, a key homing receptor on T-cells [79], promote the generation of Tregs through the secretion of TGF- $\beta$, IL-10, and IDO, increase M2 macrophages and suppress NK function by inhibiting IFN- $\gamma$ production, NKG2D expression, and cytotoxic activity [74]. 
In SS, the number of MDSCs is not increased [51]. ROS production by MDSC is increased in CTCL suggesting that MDSC activity, rather than absolute numbers in peripheral blood, may correlate with disease progression [51]. MDSCs are a heterogeneous population of immature myeloid cells that include monocytic (mMDSC) and granulocytic (gMDSC) subsets, whereas, there are few studies on Sézary syndrome, to better understand their role in the immunosuppression.

\subsection{M2 Macrophages}

Macrophages present in the tumor microenvironment are called tumor-associated macrophages (TAM), and they are characterized by the expression of CD163, a highly specific monocyte/macrophage marker for polarized M2 macrophages [64]. There are two subpopulations of macrophages. The M1 macrophages are present in Th1 responses. They are induced by IFN- $\gamma$, present antigens, and produce inflammatory cytokines such as IL-1 $\beta$, TNF- $\alpha$, IL- 6 , and IL-23, and are related to inflammation and tumor inhibition. On the other hand, M2 macrophages are part of the Th2 response, are induced by IL-4, produce IL-10 and TGF- $\beta$, and are related to an immunosuppressive microenvironment, which favors tumor cell growth, angiogenesis, matrix remodeling, and inhibition of adaptive immunity. The release of IL-32 by NK cells, T-cells, keratinocytes, and fibroblasts may increase the M2 population in CTCL [80]. CD163/CD68 ratio was the highest at the MF tumor stage and Sézary syndrome, indicating M2 polarization with disease progression [81].

The IL-4 and IL-13 Th2 cytokines induce the production of CCL18 by M2 macrophages. The CCL18 binds to CCR8, a receptor expressed by Th2, Treg cells, and eosinophils (Figure 5) $[14,82,83]$. TAMs producing CCL18 are observed in CTCL patients, and serum levels of CCL18 are associated with a poorer prognosis [64,84]. Furthermore, increased CCL22 serum levels and SCD163 serum levels in CTCL reflect the increased activity of TAMs and tumor progression to a more advanced stage [81]. A strong correlation between macrophage depletion and decreased expression of a vascular marker, CD31, and lymphatic marker, podoplanin, suggest a role for macrophages in angiogenesis. Xenografted human CTCL cells (Hut78) showed that M2-like macrophages have a role in the progression of tumor formation in the skin [85].

The phagocytic activity of macrophages is also impaired in SS. The Th2 microenvironment with increased IL-4, IL-7, and IL-13, contributes to the expression of CD47 by Sézary cells. The CD47 binds to its receptor, the signal regulatory protein $\alpha(\operatorname{SIRP} \alpha)$, on macrophages, and inhibits macrophage-mediated phagocytosis of neoplastic cells (do-noteat-me signal) (Figure 6) $[23,86]$. The blocking of CD47 in hematological malignancies showed good responses in preliminary clinical trials, and it highlights the role of phagocytosis in controlling malignant cellular growth [87].

\subsection{Neutrophils}

Neutrophils are polymorphonucleate granulocytes. They are part of the innate immune system and act by the phagocytosis of pathogens. The recognition of the pathogens occurs by the interaction of toll-like receptors (TLRs) and pathogen-associated molecular patterns (PAMPs) [88].

Neutrophils have major effector mechanisms as phagocytosis, degranulation, and Neutrophil extracellular traps (NETs) formation. NETs are composed of decondensed nuclear or mitochondrial DNA enriched by proteases and various inflammatory mediators. Cancer cells recruit neutrophils releasing NETs to the tumor microenvironment [89]. There is no evidence regarding NET production in CTCL, whereas neutrophils in peripheral blood show an activated profile. Neutrophils showed increased CD11b and CD66b and decreased CD62L, consistent with neutrophil activation [90]. Peripheral blood neutrophils in CTCL patients showed an enhanced respiratory burst and have an activated surface marker phenotype, even in the early stages of CTCL. 


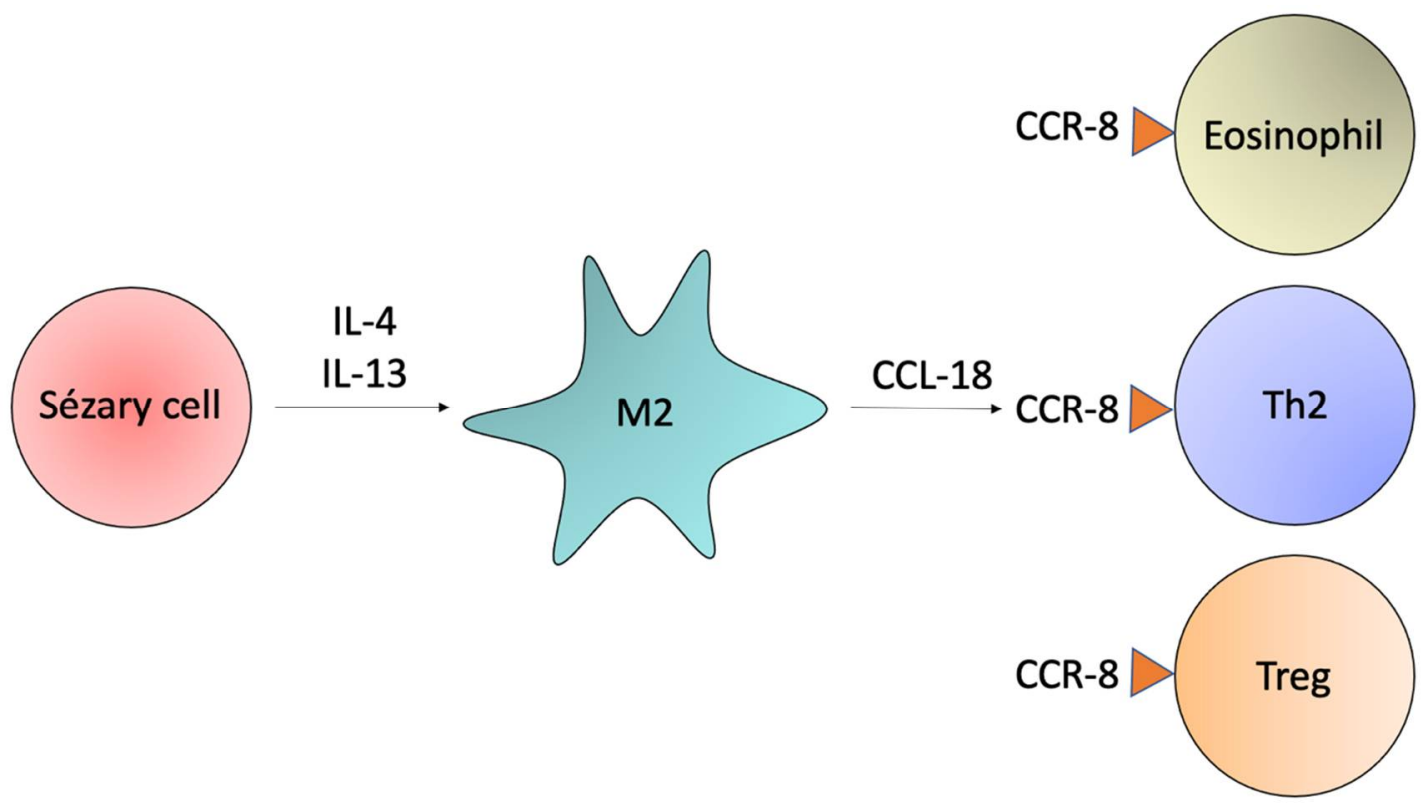

Figure 5. M2 macrophages. Sézary cells produce the Th2 cytokines IL-4 and IL-13. These cytokines stimulate M2 macrophages to produce CCL18, a chemokine that attracts CCR8+ cells to the tumor microenvironment. The CCR8 is expressed by eosinophils, Th2 cells, and Treg.
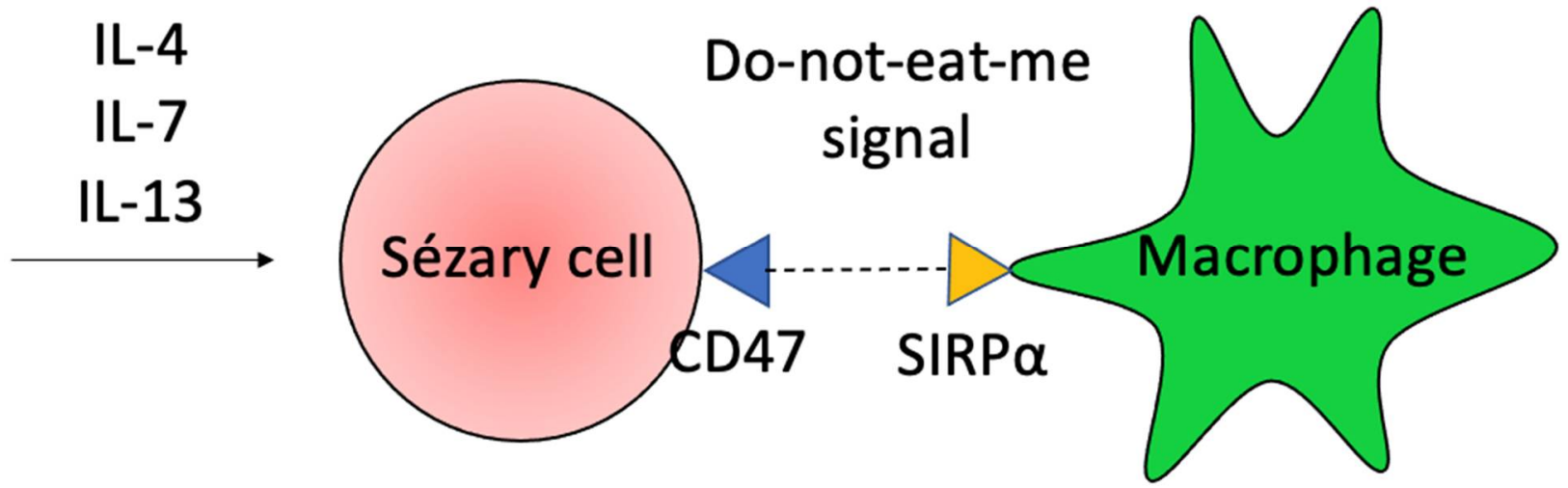

Figure 6. Do-not-eat-me signal. The Th2 microenvironment stimulates the expression of CD47 on the Sézary cell surface. It binds to SIRP $\alpha$ on macrophages and prevents phagocytosis, contributing to tumor escape.

The presence of CXCL8 that mediates neutrophil recruitment has been detected in CTCL skin lesions as well as by clonal CTCL cells [91,92]. The elevations in plasma IL-8 show a mechanism for systemic neutrophil priming and activation in CTCL.

The IL-17 is an important cytokine involved in the pathogenesis of many skin diseases, e.g., psoriasis and hidradenitis suppurativa [93,94]. The IL-17 upregulates the secretion of C-X-C receptor (CXCR)-2 ligands. Neutrophils express CXCR2 and are attracted by the Th17 microenvironment $[95,96]$. In CTCL, a relatively low expression of IL-17 is observed, which may explain the lack of neutrophil infiltration in skin lesions [97]. Besides the low number of neutrophils in SS, they are functionally impaired, with reduced phagocytic activity and intracellular killing. These defects favor the development of infections in these patients, and the impaired response against pathogens is an important cause of complications and death $[23,88]$. The expression of IL-17A and IL-17F in a JAK3/STAT3/STAT5-dependent mechanism has been observed in a subset of patients, and it has been associated with disease progression. However, these cells do not express other characteristic Th17 phenotypes, 
suggesting that the capacity to produce IL-17 derives from a dysregulated signaling rather than a true Th17 response [15,98].

\subsection{Mast Cells}

Mast cells are bone marrow-derived hematopoietic cells. They are preferentially located in the skin, airways, and gastrointestinal tract, tissues that are in direct contact with the environment $[99,100]$. Mast cells are activated by immunoglobulin E (IgE) upon its binding to the high-affinity IgE receptor present on the cell surface. After activation, mast cells secrete histamine, proteases, cytokines, and chemokines [101]. Mast cells produce different matrix metalloproteinases (e.g., MMP-9) and proteases (tryptase and chymase) and could be an important source of proangiogenic factors [102]. Mast cells have rapid sensing of microorganisms such as bacteria, parasites, fungi, and viruses, which can be recognized by TLRs, resulting in the signaling pathway for the release of multiple cytokines as well as the release of preformed granules [102].

The tumor microenvironment in solid and hematopoietic malignancies is influenced by mast cells. Its increase in neoplastic tissues is correlated with tumor stage, prognosis, and invasiveness in different malignancies [17].

In CTCL, an increased number of mast cells particularly at the periphery of tumors is also correlated with tumor microvessel density and disease progression [103]. In a mouse model with deficient mast cell mice, tumor growth significantly decreased [101]. Mast cells in CTCL tissue exhibit a degranulated phenotype, and supernatant from the activated mast cells is able to promote proliferation of the malignant CTCL cells in vitro, which shows the protumorigenic role of mast cells [101].

Mast cells and histamine may play a role in CTCL, particularly in the advanced stages of the disease [104]. Mast cells activation leads to proteinases and histamine secretion which in turn stimulates sensory nerve endings and activates keratinocytes [105]. Considering that mast cells can be regulated by neurotransmitters and neuropeptides, it is important to understand the pathophysiology of cutaneous lymphoma-associated pruritus in Sézary syndrome.

\subsection{Eosinophils}

Eosinophils are innate immune granulocytes derived from the bone marrow and are associated with helminthic infections, allergic diseases, and many inflammatory diseases (e.g., eosinophilic esophagitis, eosinophilic pneumonitis, and eosinophilic cellulitis) [106-109]. Eosinophils are recruited into sites of inflammation and release major basic protein, eosinophil cationic protein, eosinophil peroxide, eosinophil-derived neurotoxins, IL-4, IL-5, IL-13, and GM-CSF [14].

The CCL26 and CCL11 are produced by dermal fibroblasts, keratinocytes, and endothelial cells, and are increased in the skin of SS patients. The CCR3 is the receptor for CCL26 and CCL11, and it is expressed on eosinophils. Thus, the upregulation of CCL26 and CCL11 induce the migration of eosinophils to the skin [64,110]. The IL-5 and IL-13 Th2 cytokines present in the tumor microenvironment of SS patients also favor eosinophilia, and IL-4 increases IgE [23]. Activated eosinophils secrete more IL-4, IL-5, IL-13, and angiogenic factors. Thus, eosinophils contribute to tumor growth by increasing immune tolerance with a Th2 response and facilitating neovascularization [15,111]. Eosinophils produce vascular endothelial growth factors (VEGFs) and other pro-angiogenic cytokines known to play a role in tumor progression in cancer.

Eosinophils are in association with other myeloid cell types that stimulate tumorpromoting inflammation as Treg and M2 macrophages [112]. Moreover, STAT3 activation in T-cells with neoplastic morphology was significantly associated with the presence of eosinophils in CTCL. Malignant T-cells also expressed eosinophilic activation and trafficking factors, such as High-mobility group BOX-1 protein (HMGB1) and IL-5, suggesting that these cells orchestrate the accumulation and activation of eosinophils in CTCL [113]. Tissue eosinophil activation in CTCL might contribute to the inflammatory flare-ups as- 
sociated with aggressive T-cell lymphomas [114]. Blood eosinophilia at baseline should be considered a prognostic factor of poor outcome in patients with CTCL [115]. Increased IL-5 production by peripheral mononuclear cells from patients with Sézary syndrome together with eosinophilia was identified, suggesting that IFN-alpha and perhaps IL-12 may produce a therapeutic response in patients with CTCL and eosinophilia through the direct suppression of IL-5 production by malignant Sézary cells [116].

\subsection{Keratinocytes}

Keratinocytes are the most abundant cells in the epidermis. They express toll-like receptors (TLRs) that are crucial to a Th1-type immune response with the production of interferon. Keratinocytes also express MHC class II and act as non-professional antigenpresenting cells [14].

Keratinocytes are an important source of chemokines that contribute to the skinhoming of neoplastic and inflammatory cells in CTCL. The CCL17 is expressed by keratinocytes, Langerhans cells, and endothelial cells in the skin of SS patients. It binds to CCR4, present in Sézary cells. The CCL27 is constitutively produced by keratinocytes, and the erythrodermic skin of SS patients presents an increased CCL27 production compared to healthy normal skin. The receptor CCR10 is expressed on Sézary cells. Thus, the CCL17-CCR4 and CCL27-CCR10 interactions are essential to skin-homing of Sézary cells (Figure 7) [110,117].

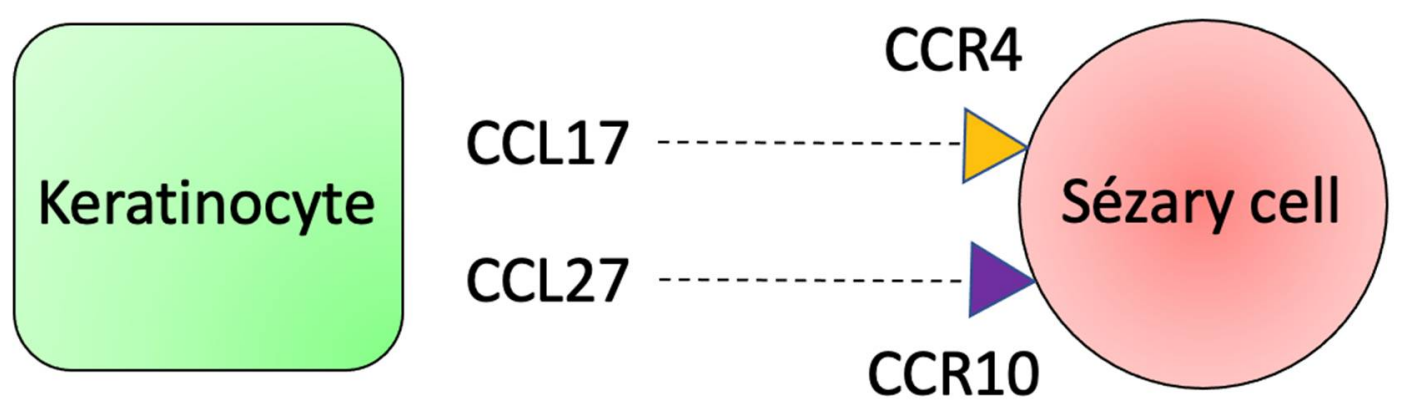

Figure 7. Keratinocytes produce CCL17 and CCL27 that bind to CCR4 and CCR10, respectively. These receptors are expressed by Sézary cells, contributing to the epidermotropism of malignant cells.

The CCL26 and CCL11 are also produced by keratinocytes, and they contribute to the migration of eosinophils by interaction with the CCR3, which favors the Th2 response (Figure 8) [64].

Periostin is an extracellular matrix protein secreted by dermal fibroblasts upon stimulation by IL-4 and IL-13. Periostin mediates thymic stromal protein (TSLP) production by keratinocytes, and TSLP subsequently activates immature DCs, which modulate Th2 immune responses via CCL17 production. Immature DCs produce IL-4, IL-5, and IL-13. Serum and plasma TSLP levels are elevated in SS [118]. TSLP also induces STAT5 activation that promotes CTCL cells proliferation and IL-4 and IL-13 production $[30,64,119,120]$. STAT5 also downregulates STAT4 and the transcription factor STAB1 (special AT-rich sequence binding protein-1) through the induction of miR-155. The STAB1 inhibits the expression of IL-5 and IL-9 in neoplastic cells, and STAT5 activation allows the expression of these cytokines favoring the Th2 response (Figure 9) [30,121]. Periostin also induces the expression of IL-25 in keratinocytes. IL-25 promotes a Th2 immune response by enhancing the expression of IL-13, and IL-13 promotes the proliferation of malignant cells [122,123]. 


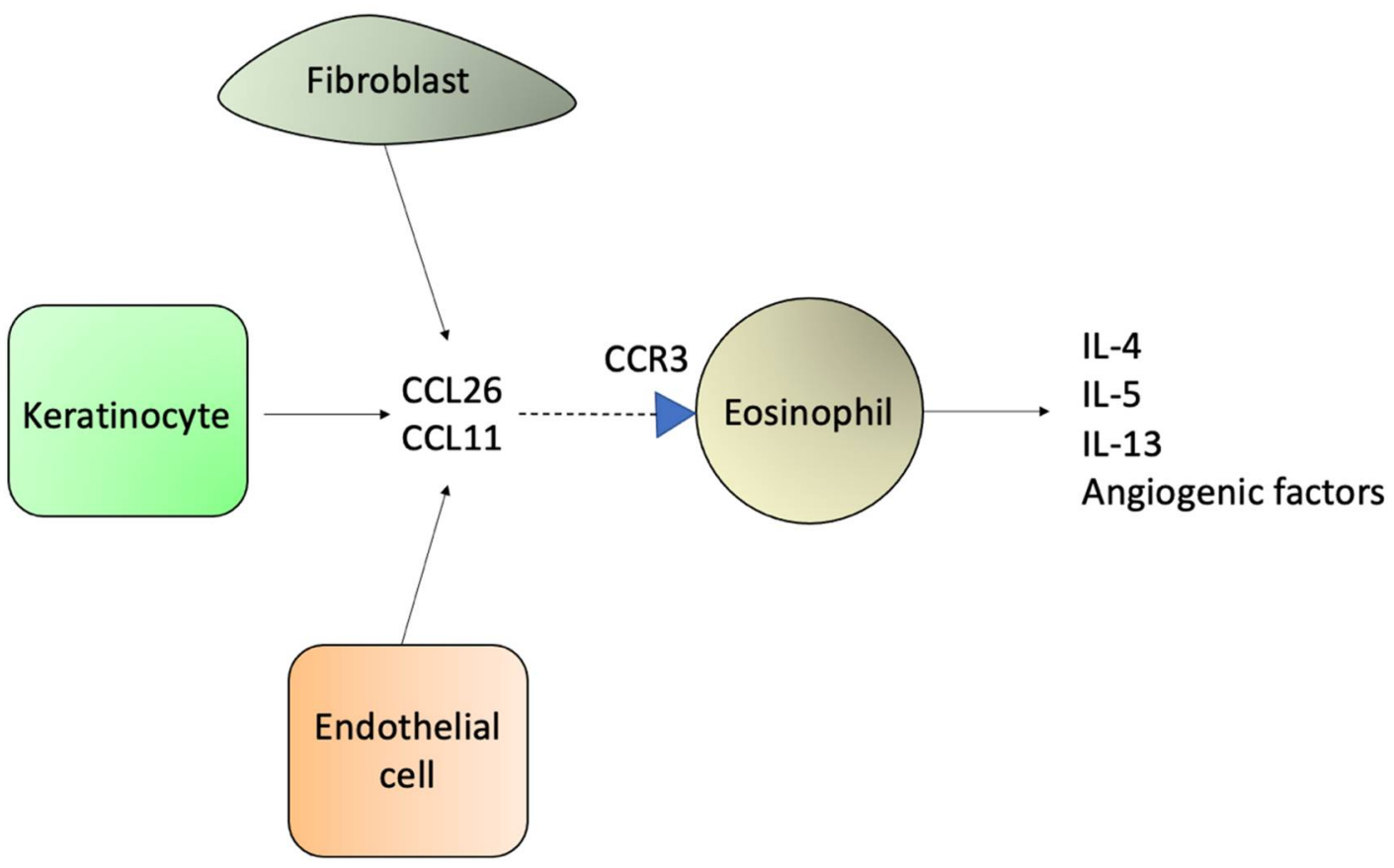

Figure 8. Keratinocytes, fibroblasts, and endothelial cells produce CCL26 and CCL11. These chemokines attract CCR3+ eosinophils.

In SS, IL-22 is increased, and it promotes CCL20 expression in keratinocytes and induces epidermal hyperplasia. The CCL20 ligand, CCR6, is expressed on immature DCs, Th17, Th22, and regulatory T-cells. The migration of immature DCs and Tregs due to the increased expression of CCL20 by keratinocytes contributes to the immunological tolerance microenvironment, especially seen in advanced cases [30,97].

The most important symptom in SS patients is pruritus. It is observed in virtually all patients with SS, and its intensity is directly correlated with a reduction in the quality of life $[3,124]$. Nerve growth factor (NGF) is produced by keratinocytes, stimulates nerve fibers growth, and is associated with the severity of pruritus. NGF serum is elevated in SS, and the enhanced expression may be associated with increased dermal nerve fibers density and severe pruritus [125].

Angiogenin is a stimulator of angiogenesis, and it also acts as an inhibitor of polymorphonuclear cell degranulation. It is produced by keratinocytes and endothelial cells, besides being elevated in SS skin, and may be related to an increased susceptibility to infections and poorer prognosis [126,127].

\subsection{Fibroblasts}

Fibroblasts are spindle-shaped cells that are responsible for the production of the structural and signaling molecules present in the extracellular matrix, e.g., collagens, proteoglycans, elastin, fibronectin, microfibrillar proteins, and laminins [128]. Cancerassociated fibroblasts (CAFs) are crucial components of the tumor microenvironment, inducing cell growth and immune escape through various mechanisms [129]. Dermal fibroblasts in advanced-stage CTCL contribute to a Th2-dominant microenvironment by increasing Th2 and attenuating Th1 immune responses [17]. 


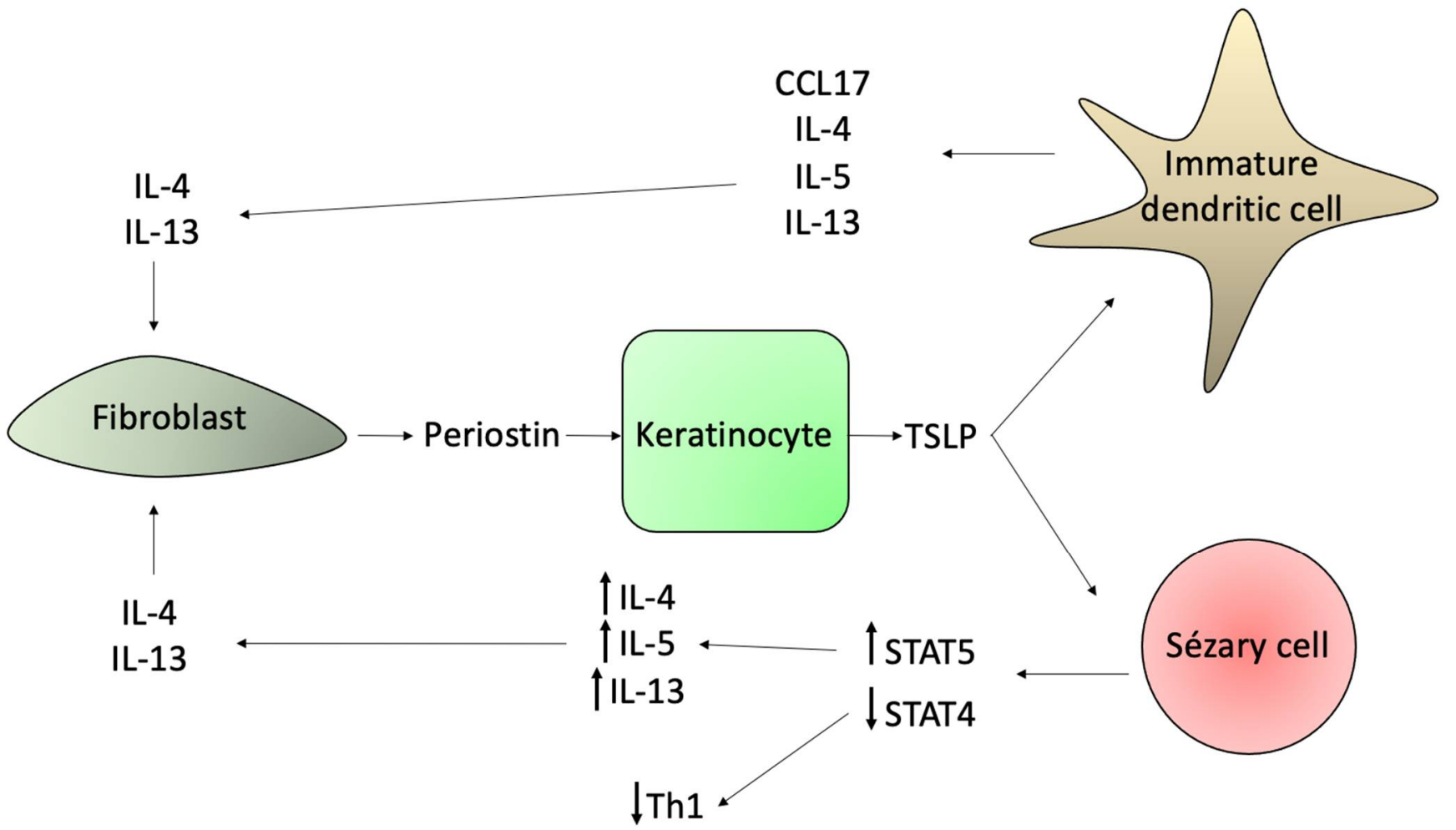

Figure 9. The role of periostin on the SS tumor microenvironment. The periostin, secreted by fibroblasts after activation by IL-4 and IL-13, stimulates TSLP production by keratinocytes. The TSLP stimulates immature DCs and Sézary cells to secrete Th2 cytokines, which will ultimately interact with fibroblasts to produce more periostin in a positive loop.

In SS, fibroblasts contribute to the Th2 microenvironment by producing CCL26, which attract CCR3+ eosinophils (Figure 8); and by secreting periostin upon IL-4 and IL-13 stimulation, which will mediate TSLP production by keratinocytes and will activate immature DCs (Figure 9) [64].

The herpesvirus entry mediator (HVEM) is a member of the tumor necrosis factor receptor superfamily. It is expressed on dermal fibroblasts of early-stage CTCL patients. The HVEM increases the production of CXCL9, CXCL10, and CXCL11, which recruit CXCR3+ Th1 cells to the skin. In advanced-stage CTCL, including SS patients, HVEM is decreased, and it attenuates the Th1 response [130]. The CXCR3 may also be expressed by malignant T-cells, and a decreased production of CXCL9, CXCL10, and CXCL11 may contribute to the loss of epidermotropism observed in SS [15]. On the other hand, fibroblasts produce CXCL12, or stromal cell-derived factor-1 (SDF-1). It is a chemoattractant for CXCR4+ tumoral cells and it is increased in the skin of SS patients. The CXCL12/SDF-1 is inhibited by CD26 peptidase activity. Since Sézary cells lack CD26, the CXCR4-CXCL12/SDF-1 axis may have an important role in the skin recruitment and accumulation of neoplastic cells [131].

\subsection{Malignant Cells}

The production of autocrine growth factors that activate pro-oncogenic pathways is observed in Sézary cells. Malignant cells are influenced by IL-4 and IL-13, which activate the STAT6 pathway. This pathway will enhance the transcription of IL-4, IL-5, and IL13 messenger RNA, and will lead to the secretion of these cytokines by the malignant cells $[15,123]$.

The IL-15 activates STAT3 and STAT5, and it acts as a tumor growth factor [132]. In neoplastic cells, ZEB1, a tumor suppressor gene that represses the transcription of IL-15, is hypermethylated. This impairs ZEB1 function, IL-15 is overexpressed and acts in an autocrine manner stimulating tumor cell growth. The IL-15 secreted by malignant cells 
also influences the microenvironment, especially the epidermal keratinocytes, that become activated and proliferate [15,133].

The IL-32 also acts in an autocrine manner. It is secreted by malignant cells and stimulates tumor growth by the NF-kB pathway activation $[15,134]$.

Cyclooxygenases (COX) are enzymes that mediate inflammation through the conversion of arachidonic acid to prostaglandin. The COX-2 is detected in malignant cells. It increases the production of prostaglandin E2 (PGE2), which in turn reduces cell-mediated immunity by inhibiting Th1 cytokine production and suppressing NK and CD8 T-cell cytotoxicity. The PGE2 may also bind to its receptor on the Sézary cell surface and promote malignant cell growth $[15,135]$.

Besides the modulation of the inflammatory microenvironment, malignant cells may suppress and kill reactive cells by cell-to-cell contact. The JAK-STAT pathway may induce the expression of CD80 and PD-L1 on malignant cells. The CD80 binds to the CTLA-4 and PD-L1 binds to the PD-1 on inflammatory lymphocytes, inhibiting their function and favoring immune evasion $[15,21,136]$.

Malignant cells express FasL that induces apoptosis upon binding to Fas on inflammatory CD8+ T-cells. On the other hand, malignant cells show fewer Fas expressions and are resistant to Fas-L-mediated apoptosis [15,137].

\section{Angiogenesis and Lymphangiogenesis}

The formation of vascular and lymphatic vessels contributes to the dissemination of malignant T-cells [30]. Neo-angiogenesis and lymphangiogenesis are analyzed by microvessel density (expression of matrix metalloproteinases 2 and 9, and CD34) or by VEGF expression (VEGF-A for angiogenesis and VEGF-C for lymphangiogenesis) [14]. In CTCL skin lesions, there is an increased number of microvessels. Moreover, VEGF is significantly expressed on these cells, and it is produced by neoplastic cells, endothelial cells, histiocytes, fibroblasts, and reactive T-cells [138-140].

Malignant T-cells produce VEGF-A by JAK and c-Jun N-terminal kinase (JNK)dependent mechanisms. The VEGF-A is a potent angiogenesis stimulator, and it also induces the expression of TSLP in keratinocytes [30,141]. Malignant T-cells also produce other pro-angiogenic factors such as IL-17F, angiopoietin-2, placental growth factor, and YKL-40 [30]. The increase in podoplanin+ lymphatic vessels is caused by the release of VECG-C. Its density is associated with disease progression $[30,142]$. Lymphotoxin- $\alpha$ $(\mathrm{LT} \alpha)$ is involved in lymphatic and secondary lymphoid structures formation. It is expressed in CTCL by a JAK3/STAT5 pathway. LT $\alpha$ acts in an autocrine manner by stimulating the expression of IL-6 in malignant cells. The LT $\alpha$, IL-6, and VEGF promote angiogenesis, which will ultimately contribute to tumor growth and spread [14].

Matrix metalloproteinases (MMPs) are a group of enzymes involved in diverse physiologic (tissue remodeling, embryogenesis) and pathologic (autoimmune diseases, cancer) functions [143]. They have proteolytic activity, cellular growth signaling, apoptosis regulation, angiogenesis, and they participate in inflammatory pathways [144]. The MMPs function is regulated by its inhibitors, tissue inhibitors of metalloproteinases (TIMPs) [143,145]. The MMPs are produced by fibroblasts, macrophages, keratinocytes, T-cells, endothelial cells, and mast cells [146]. In CTCL skin, MMP-2 and MMP-9 are increased. Malignant T-cells secrete factors that stimulate the production of MMPs by stroma cells [30]. These two metalloproteinases are upregulated in different types of cancer, and they mediate microvascular proliferation by degrading basement membranes of endothelial cells, facilitating the spread of proliferating vascular cells to the surrounding stroma $[138,146,147]$. On the other hand, in a rabbit study model, the active form of MMP- 5 was reduced in malignant T-cells [148]. Thus, the role of different MMPs in CTCL is still not fully understood. 


\section{Skin Barrier}

\subsection{Staphylococcus aureus}

Sézary syndrome skin lesions and nasal cavity display a higher incidence of Staphylococcus aureus (S. aureus) colonization [149]. This finding is similar to atopic dermatitis (AD). In SS, there is impaired production of antimicrobial peptides, including cathelicidins and $\beta$-defensins [150]. The staphylococcal enterotoxins (SEs) function as superantigens and activate STAT3 and induce IL-10 and IL-17 expression on neoplastic cells. The IL-10 is an immunosuppressive cytokine; however, if IL-17 contributes to antimicrobial defense and/or lymphomagenesis is a matter of debate [26]. The SE also triggers the expression of FoxP3 by Sézary cells in a STAT5-dependent manner, but it is not defined whether the expression of this Treg marker has any potential immune-regulatory effect produced by malignant cells [49]. The miR-155 is also STAT5-dependent, and it inhibits the Th1 STAT4 transcription factor, and SEs may contribute to the expression of this microRNA in SS (Figures 4 and 10) [27]. The malignant T-cells initially induce susceptibility towards $S$. aureus and, subsequently, initiate crosstalk between benign and malignant T-cells, resulting in the activation of pro-oncogenic pathways [15].

\subsection{Galectins}

Galectins are a family of soluble carbohydrate-binding proteins with intra and extracellular activity defined by the carbohydrate specificity and the galectin structure [151]. These lectins have been described as players in a wide variety of cellular processes crucial in immune functions and cancer progression, such as the induction of angiogenesis, resistance to apoptosis, continuous cell proliferation, cytokine secretion, and chemotaxis [152]. Not surprisingly, there are several reports of galectin involvement in many cancers, including hematological malignancies [152].

Tumor-derived galectin-1 (Gal-1) inhibits proliferation and Th1 cytokine production by nonmalignant T-cells, besides inducing Th2 cytokines and the suppression of antitumor immune responses [153]. Gal-1 also induces epidermal hyperproliferation and impairs epidermal barrier function due to the loosely packed desmosomes, which explains the increased incidence of skin infections [13,154]. Gal-1 is known also by inducing apoptosis on T-cells [155], but the lack of CD7 expression and different CD7 glycosylation in tumor cells on skin lesions and Sézary T-cell lines seems to confer Gal-1 induced apoptosis resistance to the tumor cells [156,157].

Although galectin-9 (Gal-9) is highly expressed on lesional skin, in the serum and secreted in higher amounts by patients' tumor cells [155], high doses of exogenous Galectin-9 induce apoptosis on CTCL cell lines in vitro and reduce T-cell tumor formation on a murine model [158]. 


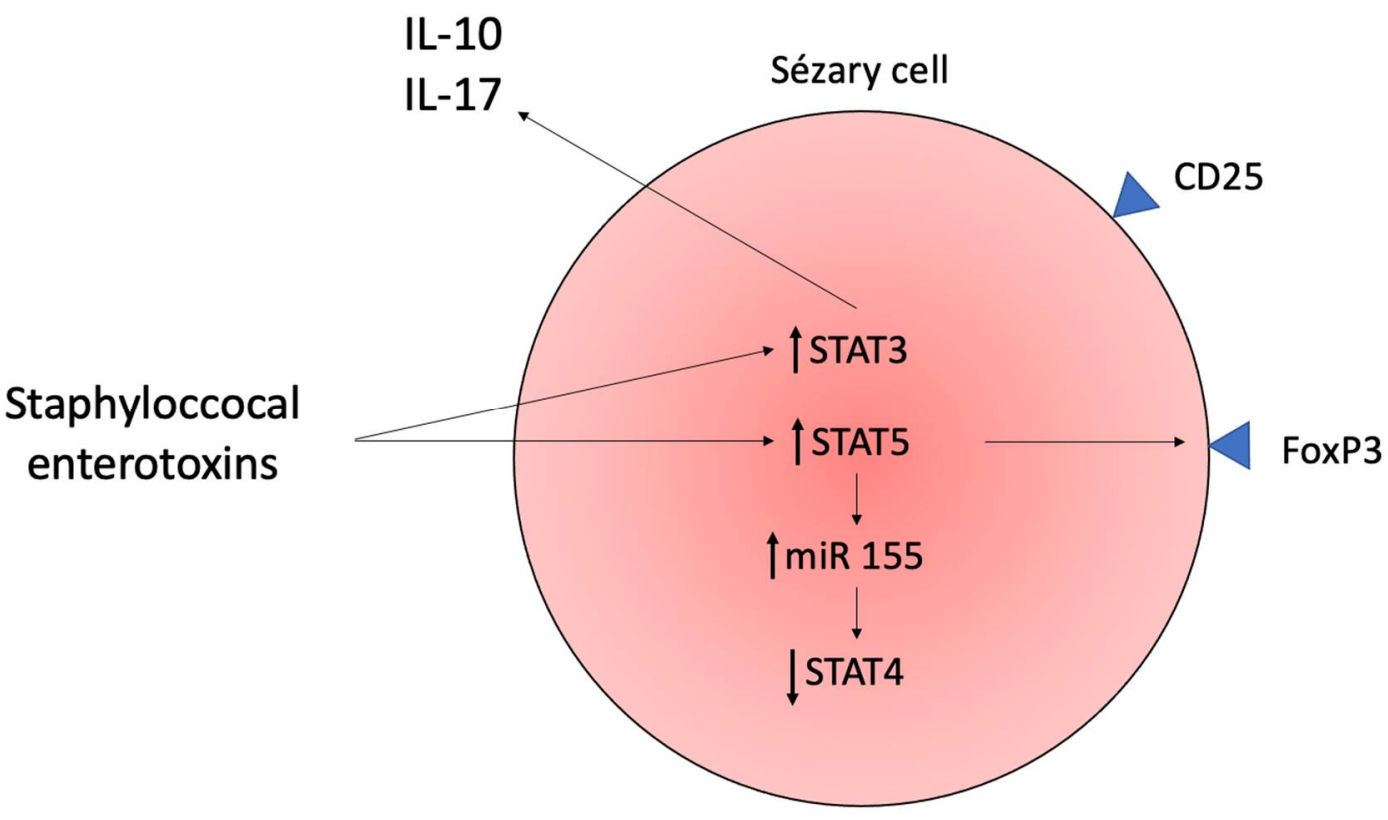

Figure 10. The interaction of Staphylococcus aureus enterotoxins in Sézary cells. The SE superantigen increases STAT3 and STAT5 function. The STAT3 pathway leads to increased production of IL-10 and IL-17. The IL-10 prevents DCs from maturating and favors the expression of the Treg phenotype in Sézary cells. The STAT5 increases production of miR-155 that inhibits the Th1 STAT4 pathway.

\section{Conclusions}

Most studies about the physiopathology of MF/SS focus on the evaluation of malignant cells. Different genetic and epigenetic alterations in SS are described and, despite the heterogeneous findings, they converge to the JAK/STAT pathway alterations, with an increased STAT3, STAT5, and STAT6 and decreased STAT4 activation. The shift from a Th1 to a Th2 immunologic response is driven by complex interactions between malignant and tumor microenvironment cells. These interactions are mediated by cytokines, chemokines, growth factors, transcription factors, and other molecules produced by a myriad of different cells. Thus, strong evidence points towards the important role of the inflammatory pro-tumorigenic environment that contributes to the immune escape of Sézary cells. Understanding the mechanisms that contribute to tumor growth and inhibition of anti-tumor response will contribute to the search for more effective treatments that not only kill malignant cells but also reestablish the normal immunologic milieu. Maybe, the combination of tumor-directed and immune-enhancing therapies may present a perspective of long-term control and even a cure for this complex and life-threatening disease.

Author Contributions: Conceptualization, D.M. and J.A.S.; writing-original draft preparation, D.M.; writing — review and editing, D.M., B.d.C.e.S., M.P.T., K.C.G.M., M.N.S. and J.A.S.; supervision, M.N.S. and J.A.S. All authors have read and agreed to the published version of the manuscript.

Funding: This research received no external funding.

Institutional Review Board Statement: Not applicable.

Informed Consent Statement: Not applicable.

Data Availability Statement: Not applicable.

Acknowledgments: We thank Juliana Pereira and Hebert Culler for the images provided.

Conflicts of Interest: The authors declare no conflict of interest. 


\section{References}

1. Sézary, A.; Bouvrain, Y. Érythrodermie avec présence de cellules monstrueuses dans le derme et le sang circulant. Bull. Société Fr. Dermatol. Syphiligr. Paris 1938, 45, 254-260.

2. Kubica, A.W.; Davis, M.D.; Weaver, A.L.; Killian, J.M.; Pittelkow, M.R. Sézary syndrome: A study of 176 patients at Mayo Clinic. J. Am. Acad. Dermatol. 2012, 67, 1189-1199. [CrossRef] [PubMed]

3. Miyashiro, D.; Sanches, J.A. Erythroderma: A prospective study of 309 patients followed for 12 years in a tertiary center. Sci. Rep. 2020, 10, 9774. [CrossRef]

4. Molloy, K.; Jonak, C.; Woei-A.-Jin, F.J.S.H.; Guenova, E.; Busschots, A.M.; Bervoets, A.; Hauben, E.; Knobler, R.; Porkert, S.; Fassnacht, C.; et al. Characteristics associated with significantly worse quality of life in mycosis fungoides/Sézary syndrome from the Prospective Cutaneous Lymphoma International Prognostic Index ( PROCLIPI ) study. Br. J. Dermatol. 2019, 182, 770-779. [CrossRef]

5. Morris, L.; Tran, J.; Duvic, M. Non-Classic Signs of Sézary Syndrome: A Review. Am. J. Clin. Dermatol. 2020, $21,383-391$. [CrossRef]

6. Willemze, R.; Jaffe, E.S.; Burg, G.; Cerroni, L.; Berti, E.; Swerdlow, S.H.; Ralfkiaer, E.; Chimenti, S.; Diaz-Perez, J.L.; Duncan, L.M.; et al. WHO-EORTC classification for cutaneous lymphomas. Blood 2005, 105, 3768-3785. [CrossRef] [PubMed]

7. Olsen, E.; Vonderheid, E.; Pimpinelli, N.; Willemze, R.; Kim, Y.; Knobler, R.; Zackheim, H.; Duvic, M.; Estrach, T.; Lamberg, S.; et al. Revisions to the staging and classification of mycosis fungoides and Sézary syndrome: A proposal of the International Society for Cutaneous Lymphomas (ISCL) and the cutaneous lymphoma task force of the European Organization of Research and Treatment of Cancer (EORTC). Blood 2007, 110, 1713-1722. [CrossRef]

8. Litvinov, I.V.; Shtreis, A.; Kobayashi, K.; Glassman, S.; Tsang, M.; Woetmann, A.; Sasseville, D.; Ødum, N.; Duvic, M. Investigating potential exogenous tumor initiating and promoting factors for Cutaneous T-Cell Lymphomas (CTCL), a rare skin malignancy. Oncoimmunology 2016, 5, e1175799. [CrossRef]

9. Nicolay, J.P.; Wobser, M. Cutaneous B-cell lymphomas-Pathogenesis, diagnostic workup, and therapy. J. Dtsch. Dermatol. Ges. 2016, 14, 1207-1224. [CrossRef]

10. Campbell, J.J.; Clark, R.A.; Watanabe, R.; Kupper, T.S. Sézary syndrome and mycosis fungoides arise from distinct T-cell subsets: A biologic rationale for their distinct clinical behaviors. Blood 2010, 116, 767-771. [CrossRef]

11. Scarisbrick, J.J.; Prince, H.M.; Vermeer, M.; Quaglino, P.; Horwitz, S.; Porcu, P.; Stadler, R.; Wood, G.S.; Beylot-Barry, M.; PhamLedard, A.; et al. Cutaneous Lymphoma International Consortium Study of Outcome in Advanced Stages of Mycosis Fungoides and Sézary Syndrome: Effect of Specific Prognostic Markers on Survival and Development of a Prognostic Model. J. Clin. Oncol. 2015, 33, 3766-3773. [CrossRef] [PubMed]

12. Trautinger, F.; Eder, J.; Assaf, C.; Bagot, M.; Cozzio, A.; Dummer, R.; Gniadecki, R.; Klemke, C.-D.; Ortiz-Romero, P.L.; Papadavid, E.; et al. European Organisation for Research and Treatment of Cancer consensus recommendations for the treatment of mycosis fungoides/Sézary syndrome-Update 2017. Eur. J. Cancer 2017, 77, 57-74. [CrossRef] [PubMed]

13. Phyo, Z.; Shanbhag, S.; Rozati, S. Update on Biology of Cutaneous T-Cell Lymphoma. Front. Oncol. 2020, 10, 765. [CrossRef]

14. Pileri, A.; Guglielmo, A.; Grandi, V.; Violetti, S.A.; Fanoni, D.; Fava, P.; Agostinelli, C.; Berti, E.; Quaglino, P.; Pimpinelli, N. The Microenvironment's Role in Mycosis Fungoides and Sézary Syndrome: From Progression to Therapeutic Implications. Cells 2021, 10, 2780. [CrossRef]

15. Krejsgaard, T.; Lindahl, L.M.; Mongan, N.P.; Wasik, M.A.; Litvinov, I.V.; Iversen, L.; Langhoff, E.; Woetmann, A.; Odum, N. Malignant inflammation in cutaneous T-cell lymphoma-a hostile takeover. Semin. Immunopathol. 2017, 39, 269-282. [CrossRef] [PubMed]

16. DeSimone, J.A.; Sodha, P.; Ignatova, D.; Dummer, R.; Cozzio, A.; Guenova, E. Recent advances in primary cutaneous T-cell lymphoma. Curr. Opin. Oncol. 2015, 27, 128-133. [CrossRef]

17. Miyagaki, T.; Sugaya, M. Immunological milieu in mycosis fungoides and Sézary syndrome. J. Dermatol. 2014, 41, 11-18. [CrossRef]

18. Quaglino, P.; Fava, P.; Pileri, A.; Grandi, V.; Sanlorenzo, M.; Panasiti, V.; Guglielmo, A.; Alberti-Violetti, S.; Novelli, M.; Astrua, C.; et al. Phenotypical Markers, Molecular Mutations, and Immune Microenvironment as Targets for New Treatments in Patients with Mycosis Fungoides and/or Sézary Syndrome. J. Investig. Dermatol. 2021, 141, 484-495. [CrossRef]

19. Torrealba, M.P.; Manfrere, K.C.; Miyashiro, D.; Lima, J.F.; Oliveira, L.D.M.; Pereira, N.Z.; Cury-Martins, J.; Pereira, J.; Duarte, A.J.; Sato, M.N.; et al. Chronic activation profile of circulating CD8+ T cells in Sézary syndrome. Oncotarget 2018, 9, 3497-3506. [CrossRef]

20. Saed, G.; Fivenson, D.P.; Naidu, Y.; Nickoloff, B.J. Mycosis Fungoides Exhibits a Th1-Type Cell-Mediated Cytokine Profile Whereas Sezary Syndrome Express a Th2-Type Profile. J. Investig. Dermatol. 1994, 103, 29-33. [CrossRef]

21. Samimi, S.; Benoit, B.; Evans, K.; Wherry, E.J.; Showe, L.; Wysocka, M.; Rook, A.H. Increased programmed death-1 expression on CD4+ T cells in cutaneous T-cell lymphoma: Implications for immune suppression. Arch. Dermatol. 2010, 146, 1382-1388. [CrossRef]

22. Guenova, E.; Watanabe, R.; Teague, J.E.; Desimone, J.A.; Jiang, Y.; Dowlatshahi, M.; Schlapbach, C.; Schaekel, K.; Rook, A.H.; Tawa, M.; et al. TH2 cytokines from malignant cells suppress TH1 responses and enforce a global TH2 bias in leukemic cutaneous T-cell lymphoma. Clin. Cancer Res. 2013, 19, 3755-3763. [CrossRef] [PubMed] 
23. Durgin, J.S.; Weiner, D.M.; Wysocka, M.; Rook, A.H. The immunopathogenesis and immunotherapy of cutaneous T cell lymphoma: Pathways and targets for immune restoration and tumor eradication. J. Am. Acad. Dermatol. 2021, 84, 587-595. [CrossRef]

24. Woollard, W.J.; Pullabhatla, V.; Lorenc, A.; Patel, V.M.; Butler, R.M.; Bayega, A.; Begum, N.; Bakr, F.; Dedhia, K.; Fisher, J.; et al. Candidate driver genes involved in genome maintenance and DNA repair in Sézary syndrome. Blood 2016, 127, 3387-3397. [CrossRef]

25. McGirt, L.Y.; Jia, P.; Baerenwald, D.A.; Duszynski, R.J.; Dahlman, K.B.; Zic, J.A.; Zwerner, J.P.; Hucks, D.; Dave, U.; Zhao, Z.; et al. Whole-genome sequencing reveals oncogenic mutations in mycosis fungoides. Blood 2015, 126, 508-519. [CrossRef]

26. Willerslev-Olsen, A.; Krejsgaard, T.F.; Lindahl, L.M.; Litvinov, I.V.; Fredholm, S.; Petersen, D.L.; Nastasi, C.; Gniadecki, R.; Mongan, N.P.; Sasseville, D.; et al. Staphylococcal enterotoxin A (SEA) stimulates STAT3 activation and IL-17 expression in cutaneous T-cell lymphoma. Blood 2016, 127, 1287-1296. [CrossRef]

27. Kopp, K.L.; Ralfkiaer, U.; Gjerdrum, L.M.R.; Helvad, R.; Pedersen, I.H.; Litman, T.; Jønson, L.; Hagedorn, P.H.; Krejsgaard, T.; Gniadecki, R.; et al. STAT5-mediated expression of oncogenic miR-155 in cutaneous T-cell lymphoma. Cell Cycle 2013, 12, 1939-1947. [CrossRef] [PubMed]

28. Litvinov, I.V.; Cordeiro, B.; Fredholm, S.; Odum, N.; Zargham, H.; Huang, Y.; Zhou, Y.; Pehr, K.; Kupper, T.S.; Woetmann, A.; et al. Analysis of STAT4 expression in cutaneous T-cell lymphoma (CTCL) patients and patient-derived cell lines. Cell Cycle 2014, 13, 2975-2982. [CrossRef]

29. Ho, I.-C.; Tai, T.-S.; Pai, S.-Y. GATA3 and the T-cell lineage: Essential functions before and after T-helper-2-cell differentiation. Nat. Rev. Immunol. 2009, 9, 125-135. [CrossRef]

30. Stolearenco, V.; Namini, M.R.J.; Hasselager, S.S.; Gluud, M.; Buus, T.B.; Willerslev-Olsen, A.; Ødum, N.; Krejsgaard, T. Cellular Interactions and Inflammation in the Pathogenesis of Cutaneous T-Cell Lymphoma. Front. Cell Dev. Biol. 2020, 8, 851. [CrossRef]

31. Vermeer, M.H.; Van Doorn, R.; Dukers, D.; Bekkenk, M.W.; Meijer, C.J.; Willemze, R. CD8+ T Cells in Cutaneous T-Cell Lymphoma: Expression of Cytotoxic Proteins, Fas Ligand, and Killing Inhibitory Receptors and Their Relationship With Clinical Behavior. J. Clin. Oncol. 2001, 19, 4322-4329. [CrossRef]

32. Tang, R.; Rangachari, M.; Kuchroo, V.K. Tim-3: A co-receptor with diverse roles in T cell exhaustion and tolerance. Semin. Immunol. 2019, 42, 101302. [CrossRef]

33. Canale, F.P.; Ramello, M.C.; Núñez, N.; Furlan, C.L.A.; Bossio, S.N.; Serrán, M.G.; Boari, J.T.; del Castillo, A.; Ledesma, M.; Sedlik, C.; et al. CD39 Expression Defines Cell Exhaustion in Tumor-Infiltrating CD8+ T Cells. Cancer Res. 2018, 78, 115-128. [CrossRef]

34. Jabri, B.; Abadie, V. IL-15 functions as a danger signal to regulate tissue-resident T cells and tissue destruction. Nat. Rev. Immunol. 2015, 15, 771-783. [CrossRef]

35. Qin, J.-Z.; Kamarashev, J.; Zhang, C.-L.; Dummer, R.; Burg, G.; Döbbeling, U. Constitutive and Interleukin-7- and Interleukin15-Stimulated DNA Binding of STAT and Novel Factors in Cutaneous T Cell Lymphoma Cells. J. Investig. Dermatol. 2001, 117, 583-589. [CrossRef]

36. Tripathi, P.; Kurtulus, S.; Wojciechowski, S.; Sholl, A.; Hoebe, K.; Morris, S.C.; Finkelman, F.D.; Grimes, H.L.; Hildeman, D.A. STAT5 Is Critical To Maintain Effector CD8+T Cell Responses. J. Immunol. 2010, 185, 2116-2124. [CrossRef]

37. Kurtulus, S.; Tripathi, P.; Moreno-Fernandez, M.E.; Sholl, A.; Katz, J.D.; Grimes, H.L.; Hildeman, D.A. Bcl-2 Allows Effector and Memory CD8+ T Cells To Tolerate Higher Expression of Bim. J. Immunol. 2011, 186, 5729-5737. [CrossRef]

38. Ribeiro, D.; Melão, A.; Van Boxtel, R.; Santos, C.I.; Silva, A.; Silva, M.C.; Cardoso, B.A.; Coffer, P.J.; Barata, J.T. STAT5 is essential for IL-7-mediated viability, growth, and proliferation of T-cell acute lymphoblastic leukemia cells. Blood Adv. $2018,2,2199-2213$. [CrossRef] [PubMed]

39. Berger, C.L.; Tigelaar, R.; Cohen, J.; Mariwalla, K.; Trinh, J.; Wang, N.; Edelson, R.L. Cutaneous T-cell lymphoma: Malignant proliferation of T-regulatory cells. Blood 2005, 105, 1640-1647. [CrossRef]

40. Safinia, N.; Scottà, C.; Vaikunthanathan, T.; Lechler, R.I.; Lombardi, G. Regulatory T Cells: Serious Contenders in the Promise for Immunological Tolerance in Transplantation. Front. Immunol. 2015, 6, 438. [CrossRef]

41. Vignali, D.A.A.; Collison, L.W.; Workman, C.J. How regulatory T cells work. Nat. Rev. Immunol. 2008, 8, 523-532. [CrossRef]

42. Krejsgaard, T.; Odum, N.; Geisler, C.; Wasik, M.A.; Woetmann, A. Regulatory T cells and immunodeficiency in mycosis fungoides and Sézary syndrome. Leukemia 2012, 26, 424-432. [CrossRef] [PubMed]

43. Heid, J.B.; Schmidt, A.; Oberle, N.; Goerdt, S.; Krammer, P.H.; Suri-Payer, E.; Klemke, C.D. FOXP3+CD25- tumor cells with regulatory function in Sezary syndrome. J. Investig. Dermatol. 2009, 129, 2875-2885. [CrossRef]

44. Whittaker, S. Global Patterns of Methylation in Sézary Syndrome Provide Insight into the Role of Epigenetics in Cutaneous T-Cell Lymphoma. J. Investig. Dermatol. 2016, 136, 1753-1754. [CrossRef]

45. van Doorn, R.; Slieker, R.C.; Boonk, S.E.; Zoutman, W.H.; Goeman, J.J.; Bagot, M.; Michel, L.; Tensen, C.P.; Willemze, R.; Heijmans, B.T.; et al. Epigenomic Analysis of Sezary Syndrome Defines Patterns of Aberrant DNA Methylation and Identifies Diagnostic Markers. J. Investig. Dermatol. 2016, 136, 1876-1884. [CrossRef] [PubMed]

46. Tiemessen, M.M.; Mitchell, T.J.; Hendry, L.; Whittaker, S.J.; Taams, L.S.; John, S. Lack of Suppressive CD4+CD25+FOXP3+ T Cells in Advanced Stages of Primary Cutaneous T-Cell Lymphoma. J. Investig. Dermatol. 2006, 126, 2217-2223. [CrossRef]

47. Krejsgaard, T.; Gjerdrum, L.M.; Ralfkiaer, E.; Lauenborg, B.; Eriksen, K.W.; Mathiesen, A.-M.; Bovin, L.F.; Gniadecki, R.; Geisler, C.; Ryder, L.P.; et al. Malignant Tregs express low molecular splice forms of FOXP3 in Sézary syndrome. Leukemia 2008, 22, 2230-2239. [CrossRef] 
48. Krejsgaard, T.F.; Willerslev-Olsen, A.; Lindahl, L.M.; Bonefeld, C.M.; Koralov, S.; Geisler, C.; Wasik, M.A.; Gniadecki, R.; Kilian, M.; Iversen, L.; et al. Staphylococcal enterotoxins stimulate lymphoma-associated immune dysregulation. Blood 2014, 124, 761-770. [CrossRef]

49. Willerslev-Olsen, A.; Buus, T.B.; Nastasi, C.; Blümel, E.; Gluud, M.; Bonefeld, C.M.; Geisler, C.; Lindahl, L.M.; Vermeer, M.; Wasik, M.A.; et al. Staphylococcus aureus enterotoxins induce FOXP3 in neoplastic T cells in Sézary syndrome. Blood Cancer J. 2020, 10, 57. [CrossRef]

50. Saulite, I.; Ignatova, D.; Chang, Y.-T.; Fassnacht, C.; Dimitriou, F.; Varypataki, E.; Anzengruber, F.; Nägeli, M.; Cozzio, A.; Dummer, R.; et al. Blockade of programmed cell death protein 1 (PD-1) in Sézary syndrome reduces Th2 phenotype of non-tumoral T lymphocytes but may enhance tumor proliferation. OncoImmunology 2020, 9, 1738797. [CrossRef] [PubMed]

51. Geskin, L.J.; Akilov, O.E.; Kwon, S.; Schowalter, M.; Watkins, S.; Whiteside, T.L.; Butterfield, L.H.; Falo, L.D. Therapeutic reduction of cell-mediated immunosuppression in mycosis fungoides and Sézary syndrome. Cancer Immunol. Immunother. 2018, 67, 423-434. [CrossRef]

52. Catalán, D.; Mansilla, M.A.; Ferrier, A.; Soto, L.; Oleinika, K.; Aguillón, J.C.; Aravena, O. Immunosuppressive Mechanisms of Regulatory B Cells. Front. Immunol. 2021, 12, 611795. [CrossRef] [PubMed]

53. Akatsuka, T.; Miyagaki, T.; Nakajima, R.; Kamijo, H.; Oka, T.; Takahashi, N.; Suga, H.; Yoshizaki, A.; Asano, Y.; Sugaya, M.; et al. Decreased IL-10-producing regulatory B cells in patients with advanced mycosis fungoides. Eur. J. Dermatol. 2018, 28, 314-319. [CrossRef] [PubMed]

54. He, Y.; Qian, H.; Liu, Y.; Duan, L.; Li, Y.; Shi, G. The Roles of Regulatory B Cells in Cancer. J. Immunol. Res. 2014, 2014, 215471. [CrossRef] [PubMed]

55. Cooper, M.; Fehniger, T.; Caligiuri, M.A. The biology of human natural killer-cell subsets. Trends Immunol. 2001, 22, 633-640. [CrossRef]

56. Maghazachi, A.A. Role of Chemokines in the Biology of Natural Killer Cells. Curr. Top. Microbiol. Immunol. 2010, 341, 37-58. [CrossRef] [PubMed]

57. Groh, V.; Wu, J.; Yee, C.; Spies, T. Tumour-derived soluble MIC ligands impair expression of NKG2D and T-cell activation. Nature 2002, 419, 734-738. [CrossRef]

58. Manfrere, K.C.G.; Torrealba, M.P.; Miyashiro, D.; Pereira, N.Z.; Yoshikawa, F.; Oliveira, L.D.M.; Cury-Martins, J.; Duarte, A.J.; Sanches, J.A.; Sato, M.N. Profile of differentially expressed Toll-like receptor signaling genes in the natural killer cells of patients with Sézary syndrome. Oncotarget 2017, 8, 92183-92194. [CrossRef] [PubMed]

59. Nakamura, K.; Nakayama, M.; Kawano, M.; Ishii, T.; Harigae, H.; Ogasawara, K. NK-cell fratricide: Dynamic crosstalk between NK and cancer cells. OncoImmunology 2013, 2, e26529. [CrossRef]

60. Bouaziz, J.-D.; Ortonne, N.; Giustiniani, J.; Schiavon, V.; Huet, D.; Bagot, M.; Bensussan, A. Circulating Natural Killer Lymphocytes Are Potential Cytotoxic Effectors Against Autologous Malignant Cells in Sezary Syndrome Patients. J. Investig. Dermatol. 2005, 125, 1273-1278. [CrossRef]

61. Eisele, G.; Wischhusen, J.; Mittelbronn, M.; Meyermann, R.; Waldhauer, I.; Steinle, A.; Weller, M.; Friese, M.A. TGF-beta and metalloproteinases differentially suppress NKG2D ligand surface expression on malignant glioma cells. Brain 2006, 129 Pt 9 2416-2425. [CrossRef]

62. Kared, H.; Martelli, S.; Ng, T.P.; Pender, S.L.; Larbi, A. CD57 in human natural killer cells and T-lymphocytes. Cancer Immunol. Immunother. 2016, 65, 441-452. [CrossRef] [PubMed]

63. Lerias, J.R.; de Sousa, E.; Paraschoudi, G.; Martins, J.; Condeco, C.; Figueiredo, N.; Carvalho, C.; Dodoo, E.; Maia, A.; CastilloMartin, M.; et al. Trained Immunity for Personalized Cancer Immunotherapy: Current Knowledge and Future Opportunities. Front. Microbiol. 2019, 10, 2924. [CrossRef]

64. Fujii, K. New Therapies and Immunological Findings in Cutaneous T-Cell Lymphoma. Front. Oncol. 2018, 8, 198. [CrossRef] [PubMed]

65. Thumann, P.; Luftl, M.; Moc, I.; Bagot, M.; Bensussan, A.; Schuler, G.; Jenne, L. Interaction of cutaneous lymphoma cells with reactive T cells and dendritic cells: Implications for dendritic cell-based immunotherapy. Br. J. Dermatol. 2003, 149, 1128-1142. [CrossRef]

66. Luftl, M.; Feng, A.; Licha, E.; Schuler, G. Dendritic cells and apoptosis in mycosis fungoides. Br. J. Dermatol. 2002, 147, 1171-1179. [CrossRef]

67. Schlapbach, C.; Ochsenbein, A.; Kaelin, U.; Hassan, A.S.; Hunger, R.E.; Yawalkar, N. High numbers of DC-SIGN+ dendritic cells in lesional skin of cutaneous T-cell lymphoma. J. Am. Acad. Dermatol. 2010, 62, 995-1004. [CrossRef]

68. He, T.; Tang, C.; Xu, S.; Moyana, T.; Xiang, J. Interferon gamma stimulates cellular maturation of dendritic cell line DC2.4 leading to induction of efficient cytotoxic T cell responses and antitumor immunity. Cell. Mol. Immunol. 2007, 4, 105-111.

69. Tada, K.; Hamada, T.; Asagoe, K.; Umemura, H.; Mizuno-Ikeda, K.; Aoyama, Y.; Otsuka, M.; Yamasaki, O.; Iwatsuki, K. Increase of DC-LAMP+ mature dendritic cell subsets in dermatopathic lymphadenitis of mycosis fungoides. Eur. J. Dermatol. 2014, 24, 670-675. [CrossRef] [PubMed]

70. Wysocka, M.; Benoit, B.M.; Newton, S.; Azzoni, L.; Montaner, L.J.; Rook, A.H. Enhancement of the host immune responses in cutaneous T-cell lymphoma by CpG oligodeoxynucleotides and IL-15. Blood 2004, 104, 4142-4149. [CrossRef] 
71. Wysocka, M.; Zaki, M.H.; French, L.E.; Chehimi, J.; Shapiro, M.; Everetts, S.E.; McGinnis, K.S.; Montaner, L.; Rook, A.H. Sezary syndrome patients demonstrate a defect in dendritic cell populations: Effects of CD40 ligand and treatment with GM-CSF on dendritic cell numbers and the production of cytokines. Blood 2002, 100, 3287-3294. [CrossRef]

72. Swiecki, M.; Colonna, M. The multifaceted biology of plasmacytoid dendritic cells. Nat. Rev. Immunol. 2015, 15, 471-485. [CrossRef]

73. Tadmor, T.; Attias, D.; Polliack, A. Myeloid-derived suppressor cells-their role in haemato-oncological malignancies and other cancers and possible implications for therapy. Br. J. Haematol. 2011, 153, 557-567. [CrossRef] [PubMed]

74. Papafragkos, I.; Markaki, E.; Kalpadakis, C.; Verginis, P. Decoding the Myeloid-Derived Suppressor Cells in Lymphoid Malignancies. J. Clin. Med. 2021, 10, 3462. [CrossRef]

75. Ohl, K.; Tenbrock, K. Reactive Oxygen Species as Regulators of MDSC-Mediated Immune Suppression. Front. Immunol. 2018, 9 , 2499. [CrossRef]

76. Rodriguez, P.C.; Quiceno, D.G.; Ochoa, A.C. L-arginine availability regulates T-lymphocyte cell-cycle progression. Blood 2007, 109, 1568-1573. [CrossRef] [PubMed]

77. Mazzoni, A.; Bronte, V.; Visintin, A.; Spitzer, J.H.; Apolloni, E.; Serafini, P.; Zanovello, P.; Segal, D.M. Myeloid Suppressor Lines Inhibit T Cell Responses by an NO-Dependent Mechanism. J. Immunol. 2002, 168, 689-695. [CrossRef] [PubMed]

78. Liu, M.; Wang, X.; Wang, L.; Ma, X.; Gong, Z.; Zhang, S.; Li, Y. Targeting the IDO1 pathway in cancer: From bench to bedside. J. Hematol. Oncol. 2018, 11, 100. [CrossRef] [PubMed]

79. Ku, A.W.; Muhitch, J.; Powers, C.A.; Diehl, M.; Kim, M.; Fisher, D.T.; Sharda, A.P.; Clements, V.K.; O’Loughlin, K.; Minderman, H.; et al. Tumor-induced MDSC act via remote control to inhibit L-selectin-dependent adaptive immunity in lymph nodes. eLife 2016, 5, e17375. [CrossRef]

80. Ohmatsu, H.; Humme, D.; Gonzalez, J.; Gulati, N.; Möbs, M.; Sterry, W.; Krueger, J.G. IL-32 induces indoleamine 2,3dioxygenase+CD1c+ dendritic cells and indoleamine 2,3-dioxygenase+CD163+ macrophages: Relevance to mycosis fungoides progression. OncoImmunology 2017, 6, e1181237. [CrossRef] [PubMed]

81. El-Guindy, D.M.; Elgarhy, L.H.; Elkholy, R.A.; Ali, D.A.; Helal, D.S. Potential role of tumor-associated macrophages and CD163/CD68 ratio in mycosis fungoides and Sezary syndrome in correlation with serum sCD163 and CCL22. J. Cutan. Pathol. 2021. [CrossRef]

82. Islam, S.A.; Ling, M.; Leung, J.; Shreffler, W.G.; Luster, A.D. Identification of human CCR8 as a CCL18 receptor. J. Exp. Med. 2013, 210, 1889-1898. [CrossRef]

83. Günther, C.; Zimmermann, N.; Berndt, N.; Großer, M.; Stein, A.; Koch, A.; Meurer, M. Up-Regulation of the Chemokine CCL18 by Macrophages Is a Potential Immunomodulatory Pathway in Cutaneous T-Cell Lymphoma. Am. J. Pathol. 2011, 179, 1434-1442. [CrossRef] [PubMed]

84. Sugaya, M.; Miyagaki, T.; Ohmatsu, H.; Suga, H.; Kai, H.; Kamata, M.; Fujita, H.; Asano, Y.; Tada, Y.; Kadono, T.; et al. Association of the numbers of CD163+ cells in lesional skin and serum levels of soluble CD163 with disease progression of cutaneous T cell lymphoma. J. Dermatol. Sci. 2012, 68, 45-51. [CrossRef]

85. Wu, X.; Schulte, B.C.; Zhou, Y.; Haribhai, D.; Mackinnon, A.; Plaza, J.A.; Williams, C.B.; Hwang, S.T. Depletion of M2-Like Tumor-Associated Macrophages Delays Cutaneous T-Cell Lymphoma Development In Vivo. J. Investig. Dermatol. 2014, 134, 2814-2822. [CrossRef]

86. Johnson, L.D.S.; Banerjee, S.; Kruglov, O.; Viller, N.N.; Horwitz, S.M.; Lesokhin, A.; Zain, J.; Querfeld, C.; Chen, R.; Okada, C.; et al. Targeting CD47 in Sezary syndrome with SIRPalphaFc. Blood Adv. 2019, 3, 1145-1153. [CrossRef] [PubMed]

87. Russ, A.; Hua, A.B.; Montfort, W.R.; Rahman, B.; Riaz, I.B.; Khalid, M.U.; Carew, J.S.; Nawrocki, S.T.; Persky, D.; Anwer, F. Blocking "don't eat me" signal of CD47-SIRPalpha in hematological malignancies, an in-depth review. Blood Rev. 2018, 32, 480-489. [CrossRef]

88. Fierro, M.T.; Cuffini, A.M.; Novelli, M.; Banche, G.; Allizond, V.; Comessatti, A.; Brizio, M.; Scalas, D.; Merlino, C.; Quaglino, P.; et al. Functional and phenotypical alterations of polymorphonuclear cells in Sézary syndrome patients. Eur. J. Dermatol. 2011, 21, 921-929. [CrossRef]

89. Masucci, M.T.; Minopoli, M.; del Vecchio, S.; Carriero, M.V. The Emerging Role of Neutrophil Extracellular Traps (NETs) in Tumor Progression and Metastasis. Front. Immunol. 2020, 11, 1749. [CrossRef] [PubMed]

90. Goddard, D.S.; Yamanaka, K.-I.; Kupper, T.S.; Jones, D.A. Activation of Neutrophils in Cutaneous T-Cell Lymphoma. Clin. Cancer Res. 2005, 11, 8243-8249. [CrossRef]

91. Cirée, A.; Michel, L.; Camilleri-Bröet, S.; Louis, F.J.; Oster, M.; Flageul, B.; Senet, P.; Fossiez, F.; Fridman, W.H.; Bachelez, H.; et al. Expression and activity of IL-17 in cutaneous T-cell lymphomas (mycosis fungoides and sezary syndrome). Int. J. Cancer 2004, 112, 113-120. [CrossRef] [PubMed]

92. Ogawa, F.; Shimizu, K.; Hamasakia, Y.-I.; Tanaka, Y.; Katayama, I.; Yamada, Y.; Tomonaga, M. Spontaneous IL-8 production by CD4(+), CD7(+) leukemia cells in erythrodermic Sézary syndrome. Leuk. Lymphoma 2002, 43, 1061-1066. [CrossRef] [PubMed]

93. Vidal, S.; Puig, L.; Carrascosa-Carrillo, J.-M.; González-Cantero, Á.; Ruiz-Carrascosa, J.-C.; Velasco-Pastor, A.-M. From Messengers to Receptors in Psoriasis: The Role of IL-17RA in Disease and Treatment. Int. J. Mol. Sci. 2021, 22, 6740. [CrossRef]

94. Scala, E.; Cacciapuoti, S.; Garzorz-Stark, N.; Megna, M.; Marasca, C.; Seiringer, P.; Volz, T.; Eyerich, K.; Fabbrocini, G. Hidradenitis Suppurativa: Where We Are and Where We Are Going. Cells 2021, 10, 2094. [CrossRef]

95. Wu, L.; Saxena, S.; Singh, R.K. Neutrophils in the Tumor Microenvironment. Adv. Exp. Med. Biol. 2020, 1224, 1-20. 
96. Metzemaekers, M.; Gouwy, M.; Proost, P. Neutrophil chemoattractant receptors in health and disease: Double-edged swords. Cell Mol. Immunol. 2020, 17, 433-450. [CrossRef]

97. Miyagaki, T.; Sugaya, M.; Suga, H.; Kamata, M.; Ohmatsu, H.; Fujita, H.; Asano, Y.; Tada, Y.; Kadono, T.; Sato, S. IL-22, but Not IL-17, Dominant Environment in Cutaneous T-cell Lymphoma. Clin. Cancer Res. 2011, 17, 7529-7538. [CrossRef]

98. Krejsgaard, T.; Ralfkiaer, U.; Clasen-Linde, E.; Eriksen, K.W.; Kopp, K.L.; Bonefeld, C.M.; Geisler, C.; Dabelsteen, S.; Wasik, M.A.; Ralfkiaer, E.; et al. Malignant cutaneous T-cell lymphoma cells express IL-17 utilizing the Jak3/Stat3 signaling pathway. J. Investig. Dermatol. 2011, 131, 1331-1338. [CrossRef]

99. Shelburne, C.P.; Abraham, S.N. The Mast Cell in Innate and Adaptive Immunity. Adv. Exp. Med. Biol. 2011, 716, 162-185. [CrossRef]

100. Tsai, M.; Grimbaldeston, M.; Galli, S.J. Mast Cells and Immunoregulation/Immunomodulation. Best Pract. Health Care 2011, 716, 186-211. [CrossRef]

101. Rabenhorst, A.; Schlaak, M.; Heukamp, L.C.; Förster, A.; Theurich, S.; von Bergwelt-Baildon, M.; Büttner, R.; Kurschat, P.; Mauch, C.; Roers, A.; et al. Mast cells play a protumorigenic role in primary cutaneous lymphoma. Blood 2012, 120, 2042-2054. [CrossRef]

102. Varricchi, G.; Galdiero, M.R.; Loffredo, S.; Marone, G.; Iannone, R.; Marone, G.; Granata, F. Are Mast Cells MASTers in Cancer? Front. Immunol. 2017, 8, 424. [CrossRef]

103. Eder, J.; Rogojanu, R.; Jerney, W.; Erhart, F.; Dohnal, A.; Kitzwögerer, M.; Steiner, G.; Moser, J.; Trautinger, F. Mast Cells Are Abundant in Primary Cutaneous T-Cell Lymphomas: Results from a Computer-Aided Quantitative Immunohistological Study. PLoS ONE 2016, 11, e0163661. [CrossRef] [PubMed]

104. Yamamoto, T.; Katayama, I.; Nishioka, K. Role of mast cell and stem cell factor in hyperpigmented mycosis fungoides. Blood 1997, 90, 1338-1340. [CrossRef] [PubMed]

105. Siiskonen, H.; Harvima, I. Mast Cells and Sensory Nerves Contribute to Neurogenic Inflammation and Pruritus in Chronic Skin Inflammation. Front. Cell Neurosci. 2019, 13, 422. [CrossRef] [PubMed]

106. Flier, J.S.; Underhill, L.H.; Weller, P.F. The Immunobiology of Eosinophils. N. Engl. J. Med. 1991, 324, 1110-1118. [CrossRef]

107. Marzano, A.V.; Genovese, G. Eosinophilic Dermatoses: Recognition and Management. Am. J. Clin. Dermatol. 2020, 21, 525-539. [CrossRef]

108. Furuta, G.T.; Katzka, D.A. Eosinophilic Esophagitis. N. Engl. J. Med. 2015, 373, 1640-1648. [CrossRef] [PubMed]

109. Barry, J.; Gadre, A.; Akuthota, P. Hypersensitivity pneumonitis, allergic bronchopulmonary aspergillosis and other eosinophilic lung diseases. Curr. Opin. Immunol. 2020, 66, 129-135. [CrossRef] [PubMed]

110. Sugaya, M. Chemokines and cutaneous lymphoma. J. Dermatol. Sci. 2010, 59, 81-85. [CrossRef]

111. Davoine, F.; Lacy, P. Eosinophil Cytokines, Chemokines, and Growth Factors: Emerging Roles in Immunity. Front. Immunol. 2014, 5, 570. [CrossRef]

112. Mao, Y.; Poschke, I.; Kiessling, R. Tumour-induced immune suppression: Role of inflammatory mediators released by myelomonocytic cells. J. Intern. Med. 2014, 276, 154-170. [CrossRef]

113. Fredholm, S.; Gjerdrum, L.M.R.; Willerslev-Olsen, A.; Petersen, D.L.; Nielsen, I.Ø.; Kauczok, C.-S.; Wobser, M.; Ralfkiaer, U.; Bonefeld, C.M.; Wasik, M.A.; et al. STAT3 activation and infiltration of eosinophil granulocytes in mycosis fungoides. Anticancer. Res. 2014, 34, 5277-5286.

114. Ionescu, M.A.; Rivet, J.; Daneshpouy, M.; Briere, J.; Morel, P.; Janin, A. In situ eosinophil activation in 26 primary cutaneous T-cell lymphomas with blood eosinophilia. J. Am. Acad. Dermatol. 2005, 52, 32-39. [CrossRef] [PubMed]

115. Tancrède-Bohin, E.; Ionescu, M.A.; de la Salmonière, P.; Dupuy, A.; Rivet, J.; Rybojad, M.; Dubertret, L.; Bachelez, H.; Lebbé, C.; Morel, P. Prognostic Value of Blood Eosinophilia in Primary Cutaneous T-Cell Lymphomas. Arch. Dermatol. 2004, 140, 1057-1061. [CrossRef] [PubMed]

116. Suchin, K.R.; Cassin, M.; Gottleib, S.L.; Sood, S.; Cucchiara, A.J.; Vonderheid, E.C.; Rook, A.H. Increased interleukin 5 production in eosinophilic Sézary syndrome: Regulation by interferon alfa and interleukin. J. Am. Acad. Dermatol. 2001, 44, 28-32. [CrossRef]

117. Fujita, Y.; Abe, R.; Sasaki, M.; Honda, A.; Furuichi, M.; Asano, Y.; Norisugi, O.; Shimizu, T.; Shimizu, H. Presence of Circulating CCR10+ T cells and Elevated Serum CTACK/CCL27 in the Early Stage of Mycosis Fungoides. Clin. Cancer Res. 2006, 12, 2670-2675. [CrossRef] [PubMed]

118. Sugaya, M. Is blocking IL-4 receptor alpha beneficial for patients with mycosis fungoides or Sézary syndrome? J. Dermatol. 2021, 48, e225-e226. [CrossRef]

119. Miyagaki, T.; Sugaya, M.; Fujita, H.; Saeki, H.; Tamaki, K. Increased serum thymic stromal lymphopoietin levels in patients with cutaneous T cell lymphoma. Clin. Exp. Dermatol. 2009, 34, 539-540. [CrossRef] [PubMed]

120. Soumelis, V.; Reche, P.A.; Kanzler, H.; Yuan, W.; Edward, G.; Homey, B.; Gilliet, M.; Ho, S.; Antonenko, S.; Lauerma, A.; et al. Human epithelial cells trigger dendritic cell-mediated allergic inflammation by producing TSLP. Nat. Immunol. 2002, 3, 673-680. [CrossRef]

121. Herrera, A.; Fredholm, S.; Cheng, A.; Mimitou, E.P.; Seffens, A.; Bar-Natan, M.; Sun, A.; Latkowski, J.-A.; Willerslew-Olsen, A.; Buus, T.B.; et al. Low SATB1 Expression Promotes IL-5 and IL-9 Expression in Sézary Syndrome. J. Investig. Dermatol. 2020, 140, 713-716. [CrossRef]

122. Nakajima, R.; Miyagaki, T.; Hirakawa, M.; Oka, T.; Takahashi, N.; Suga, H.; Yoshizaki, A.; Fujita, H.; Asano, Y.; Sugaya, M.; et al. Interleukin-25 is involved in cutaneous T-cell lymphoma progression by establishing a T helper 2-dominant microenvironment. Br. J. Dermatol. 2018, 178, 1373-1382. [CrossRef] [PubMed] 
123. Geskin, L.J.; Viragova, S.; Stolz, D.B.; Fuschiotti, P. Interleukin-13 is overexpressed in cutaneous T-cell lymphoma cells and regulates their proliferation. Blood 2015, 125, 2798-2805. [CrossRef] [PubMed]

124. Ottevanger, R.; van Beugen, S.; Evers, A.; Willemze, R.; Vermeer, M.; Quint, K. Quality of life in patients with Mycosis Fungoides and Sézary Syndrome: A systematic review of the literature. J. Eur. Acad. Dermatol. Venereol. 2021, 35, 2377-2387. [CrossRef]

125. Suga, H.; Sugaya, M.; Miyagaki, T.; Ohmatsu, H.; Fujita, H.; Kagami, S.; Asano, Y.; Tada, Y.; Kadono, T.; Sato, S. Association of Nerve Growth Factor, Chemokine (C-C motif) Ligands and Immunoglobulin E with Pruritus in Cutaneous T-cell Lymphoma. Acta Derm. Venereol. 2013, 93, 144-149. [CrossRef] [PubMed]

126. Miyagaki, T.; Sugaya, M.; Suga, H.; Akamata, K.; Ohmatsu, H.; Fujita, H.; Asano, Y.; Tada, Y.; Kadono, T.; Sato, S. Angiogenin levels are increased in lesional skin and sera in patients with erythrodermic cutaneous T cell lymphoma. Arch. Dermatol. Res. 2012, 304, 401-406. [CrossRef] [PubMed]

127. Kohnken, R.; Fabbro, S.; Hastings, J.; Porcu, P.; Mishra, A. Sézary Syndrome: Clinical and Biological Aspects. Curr. Hematol. Malign. Rep. 2016, 11, 468-479. [CrossRef]

128. Plikus, M.V.; Wang, X.; Sinha, S.; Forte, E.; Thompson, S.M.; Herzog, E.L.; Driskell, R.R.; Rosenthal, N.; Biernaskie, J.; Horsley, V. Fibroblasts: Origins, definitions, and functions in health and disease. Cell 2021, 184, 3852-3872. [CrossRef]

129. Mao, X.; Xu, J.; Wang, W.; Liang, C.; Hua, J.; Liu, J.; Zhang, B.; Meng, Q.; Yu, X.; Shi, S. Crosstalk between cancer-associated fibroblasts and immune cells in the tumor microenvironment: New findings and future perspectives. Mol. Cancer 2021, $20,131$. [CrossRef] [PubMed]

130. Miyagaki, T.; Sugaya, M.; Suga, H.; Morimura, S.; Ohmatsu, H.; Fujita, H.; Asano, Y.; Tada, Y.; Kadono, T.; Sato, S. Low Herpesvirus Entry Mediator (HVEM) Expression on Dermal Fibroblasts Contributes to a Th2-Dominant Microenvironment in Advanced Cutaneous T-Cell Lymphoma. J. Investig. Dermatol. 2012, 132, 1280-1289. [CrossRef]

131. Narducci, M.G.; Scala, E.; Bresin, A.; Caprini, E.; Picchio, M.C.; Remotti, D.; Ragone, G.; Nasorri, F.; Frontani, M.; Arcelli, D.; et al. Skin homing of Sezary cells involves SDF-1-CXCR4 signaling and down-regulation of CD26/dipeptidylpeptidase IV. Blood 2006, 107, 1108-1115. [CrossRef] [PubMed]

132. Marzec, M.; Halasa, K.; Kasprzycka, M.; Wysocka, M.; Liu, X.; Tobias, J.W.; Baldwin, N.; Zhang, Q.; Odum, N.; Rook, A.H.; et al. Differential Effects of Interleukin-2 and Interleukin-15 versus Interleukin-21 on CD4+ Cutaneous T-Cell Lymphoma Cells. Cancer Res. 2008, 68, 1083-1091. [CrossRef]

133. Mishra, A.; la Perle, K.; Kwiatkowski, S.; Sullivan, L.A.; Sams, G.H.; Johns, J.; Curphey, D.P.; Wen, J.; McConnell, K.; Qi, J.; et al. Mechanism, Consequences, and Therapeutic Targeting of Abnormal IL15 Signaling in Cutaneous T-cell Lymphoma. Cancer Discov. 2016, 6, 986-1005. [CrossRef] [PubMed]

134. Suga, H.; Sugaya, M.; Miyagaki, T.; Kawaguchi, M.; Fujita, H.; Asano, Y.; Tada, Y.; Kadono, T.; Sato, S. The Role of IL-32 in Cutaneous T-Cell Lymphoma. J. Investig. Dermatol. 2014, 134, 1428-1435. [CrossRef]

135. Kopp, K.L.M.; Kauczok, C.S.; Lauenborg, B.; Krejsgaard, T.; Eriksen, K.W.; Zhang, Q.; Wasik, M.A.; Geisler, C.; Ralfkiaer, E.; Becker, J.C.; et al. COX-2-dependent PGE2 acts as a growth factor in mycosis fungoides (MF). Leukemia 2010, 24, 1179-1185. [CrossRef] [PubMed]

136. Zhang, Q.; Wang, H.Y.; Wei, F.; Liu, X.; Paterson, J.C.; Roy, D.; Mihova, D.; Woetmann, A.; Ptasznik, A.; Odum, N.; et al. Cutaneous T Cell Lymphoma Expresses Immunosuppressive CD80 (B7-1) Cell Surface Protein in a STAT5-Dependent Manner. J. Immunol. 2014, 192, 2913-2919. [CrossRef] [PubMed]

137. Contassot, E.; Kerl, K.; Roques, S.; Shane, R.; Gaide, O.; Dupuis, M.; Rook, A.H.; French, L.E. Resistance to FasL and tumor necrosis factor-related apoptosis-inducing ligand-mediated apoptosis in Sézary syndrome T-cells associated with impaired death receptor and FLICE-inhibitory protein expression. Blood 2008, 111, 4780-4787. [CrossRef]

138. Rendón-Serna, N.; Correa-Londoño, L.A.; Velásquez-Lopera, M.M.; Bermudez-Muñoz, M. Cell signaling in cutaneous T-cell lymphoma microenvironment: Promising targets for molecular-specific treatment. Int. J. Dermatol. 2021, 60, 1462-1480. [CrossRef]

139. Pileri, A.; Agostinelli, C.; Righi, S.; Fuligni, F.; Bacci, F.; Sabattini, E.; Patrizi, A.; Pileri, S.A.; Piccaluga, P.P. Vascular endothelial growth factor A (VEGFA) expression in mycosis fungoides. Histopathology 2014, 66, 173-181. [CrossRef]

140. Karpova, M.B.; Fujii, K.; Jenni, D.; Dummer, R.; Urosevic-Maiwald, M. Evaluation of lymphangiogenic markers in Sézary syndrome. Leuk. Lymphoma 2010, 52, 491-501. [CrossRef]

141. Sakamoto, M.; Miyagaki, T.; Kamijo, H.; Oka, T.; Takahashi, N.; Suga, H.; Yoshizaki, A.; Asano, Y.; Sugaya, M.; Sato, S. Serum vascular endothelial growth factor A levels reflect itch severity in mycosis fungoides and Sézary syndrome. J. Dermatol. 2018, 45, 95-99. [CrossRef] [PubMed]

142. Jankowska-Konsur, A.; Kobierzycki, C.; Grzegrzółka, J.; Piotrowska, A.; Gomulkiewicz, A.; Glatzel-Plucinska, N.; Reich, A.; Podhorska-Okołów, M.; Dzięgiel, P.; Szepietowski, J. Podoplanin Expression Correlates with Disease Progression in Mycosis Fungoides. Acta Derm. Venereol. 2017, 97, 235-241. [CrossRef] [PubMed]

143. Kähäri, V.-M.; Saarialho-Kere, U. Matrix metalloproteinases in skin. Exp. Dermatol. 1997, 6, 199-213. [CrossRef]

144. Kessenbrock, K.; Plaks, V.; Werb, Z. Matrix metalloproteinases: Regulators of the tumor microenvironment. Cell 2010, 141, 52-67. [CrossRef]

145. Lambert, E.; Dassé, E.; Haye, B.; Petitfrère, E. TIMPs as multifacial proteins. Crit. Rev. Oncol. 2004, 49, 187-198. [CrossRef]

146. Rasheed, H.; Fawzi, M.M.T.; Abdel-Halim, M.R.E.; Eissa, A.M.; Salem, N.M.; Mahfouz, S. Immunohistochemical Study of the Expression of Matrix Metalloproteinase-9 in Skin Lesions of Mycosis Fungoides. Am. J. Dermatopathol. 2010, 32, 162-169. [CrossRef] 
147. Napoli, S.; Scuderi, C.; Gattuso, G.; di Bella, V.; Candido, S.; Basile, M.S.; Libra, M.; Falzone, L. Functional Roles of Matrix Metalloproteinases and Their Inhibitors in Melanoma. Cells 2020, 9, 1151. [CrossRef]

148. Lee, M.; Kistler, C.; Hartmann, T.B.; Li, F.; Dummer, R.; Dippel, E.; Booken, N.; Klemke, C.D.; Schadendorf, D.; Eichmüller, S.B. Immunoscreening of a cutaneous T-cell lymphoma library for plasma membrane proteins. Cancer Immunol. Immunother. 2007, 56, 783-795. [CrossRef] [PubMed]

149. Talpur, R.; Bassett, R.; Duvic, M. Prevalence and treatment of Staphylococcus aureus colonization in patients with mycosis fungoides and Sézary syndrome. Br. J. Dermatol. 2008, 159, 105-112. [CrossRef] [PubMed]

150. Wolk, K.; Mitsui, H.; Witte, K.; Gellrich, S.; Gulati, N.; Humme, D.; Witte, E.; Gonsior, M.; Beyer, M.; Kadin, M.E.; et al. Deficient Cutaneous Antibacterial Competence in Cutaneous T-Cell Lymphomas: Role of Th2-Mediated Biased Th17 Function. Clin. Cancer Res. 2014, 20, 5507-5516. [CrossRef] [PubMed]

151. Modenutti, C.; Capurro, J.I.B.; di Lella, S.; Martí, M.A. The Structural Biology of Galectin-Ligand Recognition: Current Advances in Modeling Tools, Protein Engineering, and Inhibitor Design. Front. Chem. 2019, 7, 823. [CrossRef]

152. Giordano, M.; Croci, D.O.; Rabinovich, G.A. Galectins in hematological malignancies. Curr. Opin. Hematol. 2013, 20, $327-335$. [CrossRef] [PubMed]

153. Cedeno-Laurent, F.; Watanabe, R.; Teague, J.E.; Kupper, T.S.; Clark, R.A.; Dimitroff, C.J. Galectin-1 inhibits the viability, proliferation, and Th1 cytokine production of nonmalignant $\mathrm{T}$ cells in patients with leukemic cutaneous T-cell lymphoma. Blood 2012, 119, 3534-3538. [CrossRef] [PubMed]

154. Thode, C.; Woetmann, A.; Wandall, H.H.; Carlsson, M.C.; Qvortrup, K.; Kauczok, C.S.; Wobser, M.; Printzlau, A.; Ødum, N.; Dabelsteen, S. Malignant T Cells Secrete Galectins and Induce Epidermal Hyperproliferation and Disorganized Stratification in a Skin Model of Cutaneous T-Cell Lymphoma. J. Investig. Dermatol. 2015, 135, 238-246. [CrossRef]

155. Koh, H.S.; Lee, C.; Lee, K.S.; Park, E.J.; Seong, R.H.; Hong, S.; Jeon, S.H. Twist2 regulates CD7 expression and galectin-1-induced apoptosis in mature T-cells. Mol. Cells 2009, 28, 553-558. [CrossRef]

156. Rappl, G.; Abken, H.; Muche, J.M.; Sterry, W.; Tilgen, W.; André, S.; Kaltner, H.; Ugurel, S.; Gabius, H.-J.; Reinhold, U. CD4+CD7leukemic T cells from patients with Sézary syndrome are protected from galectin-1-triggered T cell death. Leukemia 2002, 16, 840-845. [CrossRef] [PubMed]

157. Roberts, A.A.; Amano, M.; Felten, C.; Galvan, M.; Sulur, G.; Pinter-Brown, L.; Dobbeling, U.; Burg, G.; Said, J.; Baum, L.G. Galectin-1-Mediated Apoptosis in Mycosis Fungoides: The Roles of CD7 and Cell Surface Glycosylation. Mod. Pathol. 2003, 16, 543-551. [CrossRef] [PubMed]

158. Nakajima, R.; Miyagaki, T.; Kamijo, H.; Oka, T.; Shishido, N.; Suga, H.; Sugaya, M.; Sato, S. Possible therapeutic applicability of galectin-9 in cutaneous T-cell lymphoma. J. Dermatol. Sci. 2019, 96, 134-142. [CrossRef] 